\title{
Opening the Woods: Towards a Quantification of Neolithic Clearance Around the Somerset Levels and Moors
}

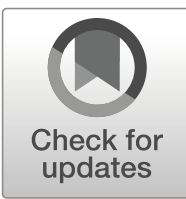

\author{
Michelle Farrell ${ }^{1,2,3}$ D $\cdot$ M. Jane Bunting ${ }^{3}$ (D) Fraser Sturt $^{4}$ (D) Michael Grant $^{5}$. \\ Gerard Aalbersberg $^{6} \cdot$ Rob Batchelor $^{7}$. Alex Brown ${ }^{8,9}$. Denise Druce ${ }^{10}$. \\ Tom Hill ${ }^{11}$ (D) Arthur Hollinrake ${ }^{12}$. Julie Jones ${ }^{13}$. Heather Tinsley ${ }^{13}$. \\ Alex Bayliss $^{14,15}$ (D) $\cdot$ Peter Marshall ${ }^{14}$ (D) $\cdot$ Suzi Richer ${ }^{16,17}$ (D) $\cdot$ Alasdair Whittle $^{18}$
}

Published online: 21 September 2019

(C) The Author(s) 2019

\begin{abstract}
Environmental reconstructions from pollen records collected within archaeological landscapes have traditionally taken a broadly narrative approach, with few attempts made at hypothesis testing or formal assessment of uncertainty. This disjuncture between the traditional interpretive approach to palynological data and the requirement for detailed, locally specific reconstructions of the landscapes in which people lived has arguably hindered closer integration of palaeoecological and archaeological datasets in recent decades. Here we implement a fundamentally different method for reconstructing past land cover from pollen records to the landscapes of and around the Somerset Levels and Moors - the Multiple Scenario Approach (MSA) - to reconstruct land cover for a series of 200-year timeslices covering the period 4200-2000 cal BC. Modelling of both archaeological and sediment chronologies enables the integration of reconstructed changes in land cover with archaeological evidence of contemporary Neolithic human activity. The MSA reconstructions are presented as a series of land cover maps and as graphs of quantitative measures of woodland clearance tracked over time. Our reconstructions provide a more nuanced understanding of the scale and timing of Neolithic clearance than has previously been available from narrative-based interpretations of pollen data. While the archaeological record tends to promote a view of long-term continuity in terms of the persistent building of wooden structures in the wetlands, our new interpretation of the palynological data contributes a more dynamic and varying narrative. Our case study demonstrates the potential for further integration of archaeological and palynological datasets, enabling us to get closer to the landscapes in which people lived.
\end{abstract}

Electronic supplementary material The online version of this article (https://doi.org/10.1007/s10816-01909427-9) contains supplementary material, which is available to authorized users.

Alasdair Whittle

whittle@cardiff.ac.uk

Extended author information available on the last page of the article 
Keywords Somerset Levels and Moors · Multiple Scenario Approach · Chronological modelling $\cdot$ Palynology $\cdot$ Neolithic $\cdot$ Land cover $\cdot$ Clearance

\section{Introduction}

Despite a long history of collaboration between palaeoecologists and archaeologists in Britain and Ireland (e.g. Clark and Godwin 1962; Coles et al. 1973), it is often argued that closer integration of palaeoecological and archaeological datasets is still required in order to fully interpret past landscapes (e.g. Chapman and Gearey 2000). Within the archaeological literature, there is a disjuncture between broad interpretive interest in landscape (e.g. Tilley 1994; Edmonds 1999) and detailed, locally specific reconstruction of the settings in which Neolithic people lived. One symptom of this is that the majority of recent archaeological syntheses of the Neolithic period in Britain do not much exploit the pollen record (Bradley 2007; Thomas 2013). Vicki Cummings (2017, p. 73) notes the complex phenomenon of the elm decline in the early Neolithic, and touches on cycles of 'woodland clearance and regrowth' in the late Neolithic (Cummings 2017, pp. 180-181), while Keith Ray and Julian Thomas claim both swift and extensive removal of tree cover in the early Neolithic (2018, pp. 72, 203). In parallel research on the chalkland of southern England, based on molluscan and soil analysis, there is a growing tendency to doubt that uninterrupted tree cover was the natural baseline at the start of the Neolithic (French et al. 2007; Pollard et al. 2012; Allen 2017).

Just as earlier headlines were hogged by discussions of landnám (or initial land taking and clearance of woodland for agriculture: Iversen 1941, 1949), the pollen record in Britain and Ireland currently tends to only be referenced in discussion of specific horizons, such as in recent debate about possible discontinuity of cereal cultivation in the later fourth millennium cal BC (Stevens and Fuller 2012; cf. Cummings 2017, pp. 180-181). The geographical scope of that particular debate also appears typical, the argument being conducted on the basis of country-wide syntheses. One recent account does engage with a wide range of evidence for the nature of Neolithic woodland, including conventional pollen analysis, and with local case studies (especially in Scotland, but also including a case study of the Somerset Levels), but the overriding emphasis is in the end on the conceptual and symbolic relationships between groups of people and the wooded environments which they inhabited (Noble 2017). Other exceptions to the under-exploitation of the pollen record come from Ireland, where the locations of archaeological features and pollen-bearing deposits - classically peat - more often coincide, especially in the north east, the centre and the west, as in the study of the Ceíde Fields (Molloy and O'Connell 1995; Whittle et al. 2011). Interpretation of radiocarbon-dated pollen diagrams has also been part of the Cultivating Societies project in Ireland (Whitehouse et al. 2014), though that too has tended to operate at a high level of synthesis within a fairly broad chronology, focusing on specific horizons such as the elm decline.

Vegetation reconstruction from pollen analysis presents its own challenges, since each pollen record reflects a sample of the vegetation present in and around the sediments sampled within a variable spatial area (see, e.g. Hellman et al. 2009). The majority of reconstructions are based on qualitative or semi-quantitative interpretation of individual site records, which are usually located where the 'best' (e.g. deepest) 
pollen-preserving sediments are found rather than at the location of contemporary human activity, or large scale, based on the aggregate patterns that emerge when many pollen records are combined (e.g. Grant et al. 2011; Woodbridge et al. 2014). Even where pollen studies are undertaken in close proximity to, or in conjunction with, archaeological investigations, the diverse theoretical and methodological underpinnings of both disciplines mean that we need to formulate and employ different approaches, models and ways of working to achieve integration between them (Perry et al. 2016). The approach employed here provides one method for scaling up from single-site palaeoecological records to full landscape reconstructions, addressing the issue of pollen sampling sites rarely being located near to areas of contemporary human activity.

From the earliest discussions of landnám in Scandinavia, Neolithic impact on land cover in north west Europe as a whole, including Britain and Ireland, has been framed in terms of replacing tree cover with open vegetation. Openness, mainly identified in pollen records through rising proportions of non-tree pollen types or increases in pollen from plants of disturbed, open or farmed habitats (anthropochores or anthropogenic indicator species; e.g. Behre 1981), is sometimes treated as a proxy for levels of human population or intensity of activity, although interpretation of this signal is not clear cut. Tree-free areas within wooded landscapes can occur due to natural processes (e.g. wind-throw, flooding, lightning strikes, disease), and there has been considerable recent debate regarding the role that large herbivorous mammals such as bison, elk and aurochs may have played in the formation and maintenance of clearings in the early Holocene 'wildwood' (e.g. Vera 2000; Svenning 2002; Mitchell 2005; Whitehouse and Smith 2010). Clearings can also be formed by human activity which could be deliberate (e.g. ring-barking, felling), or as an unintentional consequence of other activity (e.g. introduction of grazing animal species such as sheep, which tend to suppress tree regeneration). Naturally formed clearings may also be exploited by humans for grazing of sheep/goats, cattle and pigs and as a source of food, fuel and building materials. Natural gaps in woodland canopy are recolonised by trees through successional processes over multiple decades, although some natural disturbance events may slow down this process (e.g. fire, or the presence of large herbivores like deer or aurochs). Human activity in both natural and created clearings can also extend the length of time taken for recolonisation to occur via mechanisms such as repeated re-felling of natural regrowths or control of the movement of domesticated herbivores. In addition, prehistoric activity could occur in one location over a long period of time, or move within the landscape over relatively short timescales, creating a mixture of actively exploited clearings and areas of woodland regeneration. In this paper, we follow the terminology proposed by Tony Brown (1997), using the term 'clearings' for openings in the woodland canopy regardless of the cause of that opening, and the term 'clearance' for those clearings where human agency is actively involved, directly or indirectly, in their creation or persistence.

Palaeoenvironmental data are critical for assessing the presence of clearings within prehistoric woodland, as well as the overall degree of openness of the landscape, and much recent palaeoenvironmental work has attempted to test the 'Vera hypothesis' that proposes a relatively open structure for the early Holocene 'wildwood' in north west Europe (e.g. Mitchell 2005; Whitehouse and Smith 2010; Smith et al. 2010). These studies did not attempt to quantify the level of openness, however, and whilst earlier research programmes using pollen records to explore the landscapes of human 
settlement assumed that the proportion of non-arboreal pollen types (NAP) could be used as a proxy for landscape openness (e.g. Berglund et al. 1991, 1996), Sugita et al. (1999) used a simulation approach to show that NAP percentages give only a rough first approximation of the percentage cover of open land. The relationship between $\%$ NAP and the actual proportion of openings in the landscape near the pollen sampling site varies depending on the overall openness of the regional vegetation and on the characteristics of the location providing the record. Models of the relationship between pollen signals and vegetation composition in the landscape around a sampling point (e.g. Prentice 1985, 1988; Sugita 1993, 1994) have been shown to enable improved estimates of landscape openness at different scales (e.g. Fyfe et al. 2013; Hultberg et al. 2015; Trondman et al. 2015), and the PAGES LandCover6k project seeks to reconstruct proportions of the main land cover types, including open land, for the globe at key time points using the Landscape Reconstruction Algorithm (LRA: Sugita 2007a, 2007b; Trondman et al. 2015).

The same mathematical models have also been used to conduct 'thought experiments', using simulations of different arrangements of vegetation to investigate how, and whether, the pollen signal is actually affected by changes in land cover. This approach has been used to explore a range of archaeological landscape questions, including comparing possible structures of vegetation communities on Achill Island, western Ireland, in the earliest Neolithic (Caseldine et al. 2007), estimating the probable area of disturbed and open land around the early Neolithic hall at Warren Fields, north east Scotland (Tipping et al. 2009), exploring the landscape setting of rock art (Hjelle and Lødøen 2017), and investigating the changing spatial sensitivity of pollen records at different points in prehistory in Sweden (Hellman et al. 2009).

Comparing the modelled pollen signals from different landscape arrangements can also be used on a larger scale to reconstruct past land cover, and this method is termed the Multiple Scenario Approach (MSA: Bunting and Middleton 2009; Bunting et al. 2018). In the MSA, spatial grids defining known past environmental constraints for a particular landscape are combined with simple ecological principles in a probabilistic manner (e.g. oak does not occur above $700 \mathrm{~m}$ altitude, and so the probability of oak occurring in woodland below this altitude in different proportions is calculated) to generate a large number of possible land cover maps. Pollen assemblages are simulated for each map and then compared with actual pollen assemblages recovered from that landscape to determine which of the possible maps produces a pollen signal closest to the one produced by the actual past landscape (see Supplementary Information S1 for more information).

\section{Towards a quantification of Neolithic clearance around the Somerset Levels and Moors}

This research was undertaken within a major project, The Times of Their Lives (Whittle 2018; and see Acknowledgements), aimed at enhancing chronological precision in Neolithic studies, and followed a detailed study of the early Neolithic in southern Britain (Whittle et al. 2011). We set out to use the Somerset Levels and Moors to investigate the potential and limits of pollen records as a tool for identifying the locations and intensity of past impacts on the landscape, specifically by quantifying clearance using pollen dispersal and deposition models within the MSA framework. 
The Somerset Levels and Moors were selected as an example where a landscape-scale approach could be applied to both archaeological remains and pollen studies, with an emphasis on probabilistic modelling not only of archaeological and sediment chronologies but also of past land cover. The dynamic nature of the wetlands adds an extra layer of complication to reconstructing dryland vegetation from the pollen record (e.g. Binney et al. 2005), with data only available from the Levels and Moors themselves, whilst human activity undoubtedly was affecting land cover in all parts of the landscape, including the surrounding hills.

Specifically, we aim to do the following:

- Apply the 'thought experiment' approach to investigate the ability of pollen records collected from different types of wetland in the Somerset Levels and Moors to detect the presence of clearings and clearances in what was in the Neolithic a largely wooded landscape

- Use the MSA to reconstruct land cover for a series of 200-year intervals ('timeslices') covering the period 4200-2000 cal BC using existing pollen assemblages from multiple locations

- Compare reconstructed changes in land cover, with a particular focus on clearings and clearances, to archaeological evidence for contemporary Neolithic human activity in the landscapes of and around the Somerset Levels and Moors

- Demonstrate the potential of models of pollen-vegetation relationships to improve the integration of archaeological and palynological studies, and the value of considering a regional spatial scale in studies of prehistoric human activity in the landscape.

We begin with a summary of previous research in the Somerset Levels and Moors, before presenting Bayesian chronological models for the archaeology of the region to enable comparison of the archaeological and palaeoenvironmental data. We then apply a 'thought experiment' approach to investigate the potential of pollen records from the Levels and Moors to detect the presence of clearings in the largely wooded surrounding dryland landscape, before using the MSA to estimate the scale of clearance associated with human activity in the region over the period from 4200 to 2000 cal BC. Finally, we discuss the implications of our findings for interpretation of human activity in the Somerset Levels and Moors and further afield, and the potential for closer integration of archaeological and palaeoenvironmental data in future studies.

\section{Study Area and Previous Research}

The Somerset Levels and Moors (Fig. 1), one of England's largest lowland wetland areas, consist of extensive floodplain deposits in the valleys of the present Rivers Axe, Brue, Yeo and Parrett in central Somerset covering an area of $650 \mathrm{~km}^{2}$. The inland peat-dominated 'Moors' and the coastal clay belt or 'Levels' are surrounded by high ground, to the north the Mendip Hills, to the south the Blackdown Hills and to the west the Quantock Hills. The Polden Hills, an outcrop of Permo-Triassic to Lower Jurassic rocks (Green 1992), essentially divide the area into southern and northern zones. More than a hundred 'islands' that rise above the floodplain are found within the valleys and have attracted humans throughout the Holocene. 


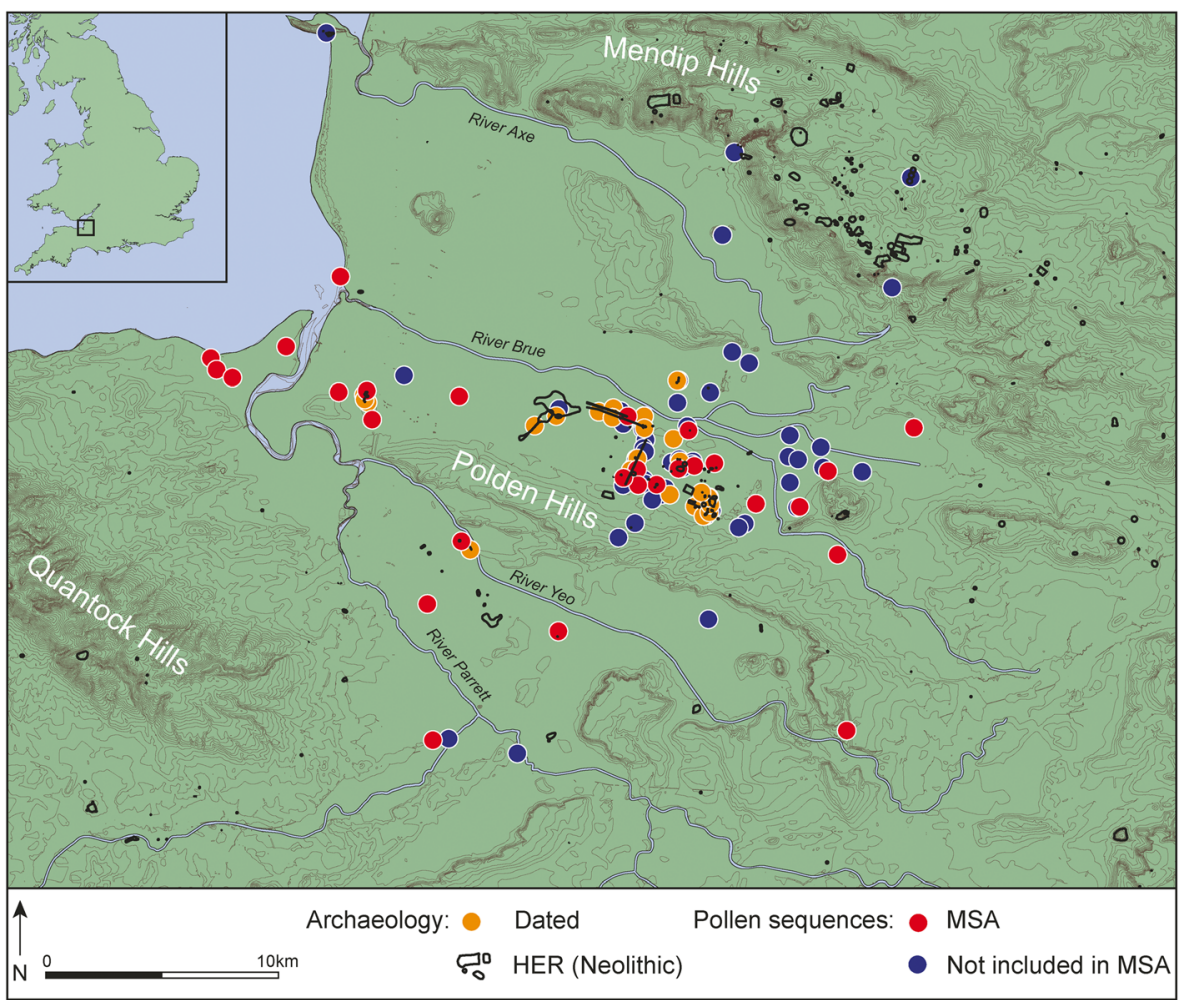

Fig. 1 Study area with location of archaeological sites and pollen sequences. Pollen sequences not used in the MSA modelling include undated sequences and those that do not include samples dating from the study period 4200-2000 cal BC

The Levels and Moors have seen extensive archaeological and palaeoecological investigations over more than a century (Brunning 2013, pp. 8-15). The first palynological studies undertaken within the Somerset Levels were by Gunnar Erdtman (1928, pp. 152153), focusing on arboreal pollen contained within the peat layers at Highbridge, Cossington and Meare Lake Village, Shapwick. Following the work of Erdtman, palynological research on the Somerset Levels and Moors aimed to reconstruct the development of later prehistoric vegetation and environment and understand the influence of relative sea level change (Godwin 1941, 1960).

Environmental studies undertaken as part of the Somerset Levels Project (SLP) from 1973 to 1989 , along with a well-funded programme of radiocarbon dating, resulted in the recognition of localised Neolithic clearance on the sandy islands of the Burtle Beds (Coles et al. 1973), together with the publication of the 'classic' vegetation sequence for the region during the Neolithic and Bronze Age (Beckett and Hibbert 1978). Integration of environmental specialists with archaeologists was a central tenet of the SLP, enabling the environmental setting of the excavated wooden structures to be reconstructed and landscape development from the late Mesolithic onwards investigated (Coles and Coles 1986; Coles 1989). Environmental reconstructions of the settings of archaeological sites such as Glastonbury Lake Village (Housley 1988; Aalbersberg and Brown 2011; Hill et al. 2019) or as part of developer-funded projects (Tinsley 2000) have characterised more recent work, 
together with investigations along the coastal fringe of the Severn Estuary (Druce 2000; Sturt et al. 2016). Since the end of the SLP, only a handful of sites have been investigated within the Levels and Moors, with most funded research concentrating on how to manage the threatened resource (Brunning 2013).

The spatial and temporal resolution of reconstructions of the landscape that prehistoric people would have inhabited has for the most part not improved since the late 1970s, a notable exception being the well-dated and close pollen sampling resolution undertaken on a monolith from close to the southern terminal of the Sweet Track (Wells et al. 1999). This has been due to an overriding interest in focusing on the palaeogeography, in particular the timing and extent of marine influence on the Somerset Levels and Moors (Aalbersberg 2000; Aalbersberg and Brown 2011; Haslett et al. 2001), and the relatively small numbers of radiocarbon determinations obtained from sediment sequences.

\section{Archaeological Chronological Modelling}

The archaeological chronologies included in this paper are based on a review of 116 radiocarbon measurements on archaeological samples (Table S2a) and tree-ring dates for four structures (Table S2b, Hillam et al. 1990). We have considered all dating evidence associated with sites that cover the later fifth to the later third millennium cal BC in the Somerset Levels and Moors. This covers a total of 41 archaeological structures or sites.

The archaeological chronological modelling has been undertaken using the program OxCal v4.2 (Bronk Ramsey 2009) and IntCal13 (Reimer et al. 2013). The archaeological chronological models are described in the Supplementary Information (S2), and are defined exactly by the brackets and OxCal CQL2 keywords on the left-hand side of the technical graphs (http://c14.arch.ox.ac.uk/). The posterior density estimates output by the model are shown in black, with the unconstrained calibrated radiocarbon dates shown in outline. The other distributions correspond to aspects of the model. For example, build_structure_16 is the estimated date when Structure 16 at Walpole was constructed (Fig. S2b). In the text and tables, the highest posterior density intervals of the posterior density estimates produced by the models are given in italics, followed by a reference to the relevant parameter name and the figures in which the model which produced it is defined. Key parameters for the chronology of human activity are listed in Table S2c.

Formal modelling of the ages from archaeological contexts not only enables more precise chronologies for the dates of construction of individual structures, but allows us to characterise the duration and timing of different building methods, and then to combine these into a much more differentiated narrative than has previously been available. Below, we outline what we think are the key elements in that narrative (see Supplementary Information S2 for further detail).

\section{The Beginning of the Neolithic in the South West of England}

Figure 2 shows estimates for the beginnings and endings of the earliest Neolithic activity associated with diagnostic early Neolithic material (Whittle et al. 2011, p. 731) in south west England from sites other than enclosures, together with estimates for the currency of other material (e.g. pits, human bone and domesticated animals) dated to the fourth millennium that was not associated with diagnostic early Neolithic material (see Figs. S2o-S2s for 
models from which this summary is derived). Structures built on the Somerset Levels and Moors have been modelled along with other material dated to the fourth millennium (Phase ${ }^{1}$ Other Context) as, apart from the Sweet Track, none are associated with diagnostic early Neolithic material.

It thus seems probable that the Levels and Moors were utilised from the very earliest Neolithic in the south west (3975-3805 cal BC (95\% probability; start_Neolithic_settlement; Fig. 2), probably 3890-3805 cal BC (68\% probability)) and that their exploitation continued after the first enclosures were constructed in 37353650 cal BC (95\% probability; first_SW_enclosure; Fig. 2), probably 3700-3660 cal BC (68\% probability).

\section{Activity Through the Neolithic in the Somerset Levels and Moors}

Figure 3 is a schematic diagram summarising the estimated dates for the building of structures across the Somerset Levels and Moors from 4400 to $2000 \mathrm{cal}$ BC. The horizontal bars represent the probability that a particular structure was built in a particular 100-year period (light shading is less probable, darker shading more probable). These distributions have been taken from the models defined in Supplementary Information S2.

\section{Architectural Practices}

Figure 4 summarises the model for the construction and use of tracks made of timber, roundwood/brushwood and hurdles respectively. The first structures to be built were timber tracks (77.5\% probability) in use from 4065-3835 cal BC (95\% probability; start_timber_tracks; Fig. 4), probably 3915-3835 cal BC (68\% probability). Construction using roundwood/brushwood and hurdles (by their nature using roundwood) probably began in the second quarter of the fourth millennium cal BC (Table S2d). This change in the use of woodland resources and in building techniques occurred some centuries after the first timber trackways were built. The construction of brushwood tracks may have ended before that of tracks built using hurdles (Fig. 4). Overall, the picture suggested by the trackway and other archaeological evidence is of sustained use of the Levels and Moors through the Neolithic, century after century (cf. Coles and Coles 1992), but it is difficult using that evidence alone to get at possible variation in the intensity of land use and settlement, apart from instances such as the Sweet Track where the preserved timbers suggest difference in the presence and location of primary and secondary woodland (Coles and Coles 1986).

\section{Land Cover Reconstruction}

All analyses described in this section were performed using the software package LandPolFlow (Bunting et al. 2018). Technical details are outlined in Supplementary Information S1. Here we focus on the decisions and assumptions which were made in developing the reconstructions of Neolithic land cover.

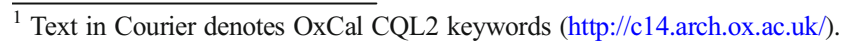




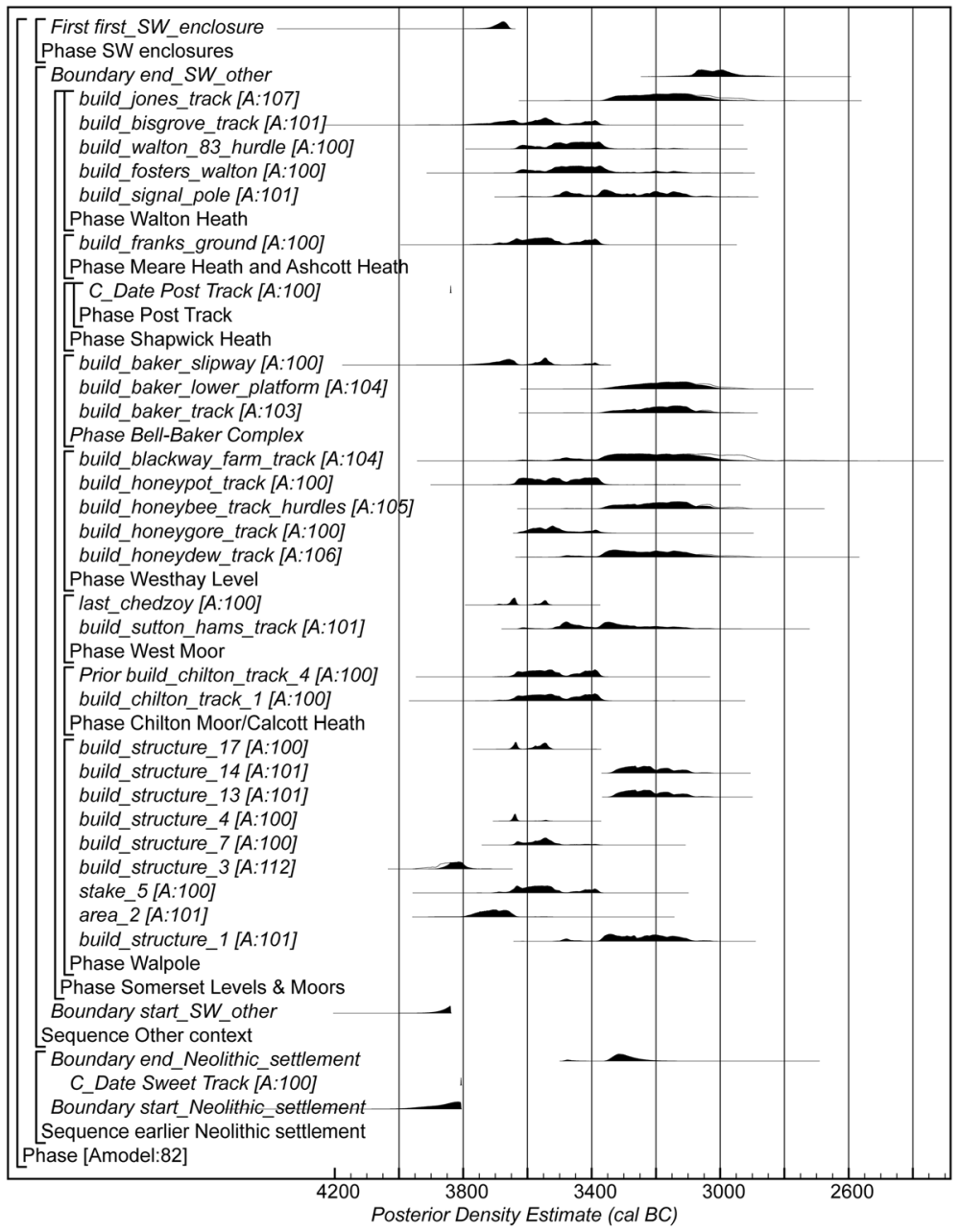

Fig. 2 Probability distributions of dates associated with diagnostically early Neolithic material (excluding those from enclosure sites), from enclosures, and from fourth millennium activity not associated with early Neolithic material (including structures built on the Somerset Levels and Moors). The distributions are derived from the model shown in Figs. S2o-S2s

We began by considering that, before historic and modern drainage, the Somerset Levels and Moors could be broadly divided into two parts: a wetland landscape which was at least seasonally waterlogged and supported vegetation with a distinctly hydrophilic character, and a dry landscape which was reasonably well-drained, occurring both on topographic 'islands' within the wetland area and on the surrounding hills. We assumed that the wetland landscape supported a complex of different types of wetland: in the western Levels where tidal influences were dominant, saltmarsh, reed swamp and mudflats; in the eastern Moors, floodplain and carr wet woodlands; and that there was mixed deciduous woodland on the dryland areas (see Fig. 5). The modelled distribution of wetlands was highly simplistic compared to a real dynamic wetland, and constrained in part by the modern distribution of sedimentary units of wetland character, partly due to a lack of robust information about the palaeogeography of the landscape. 


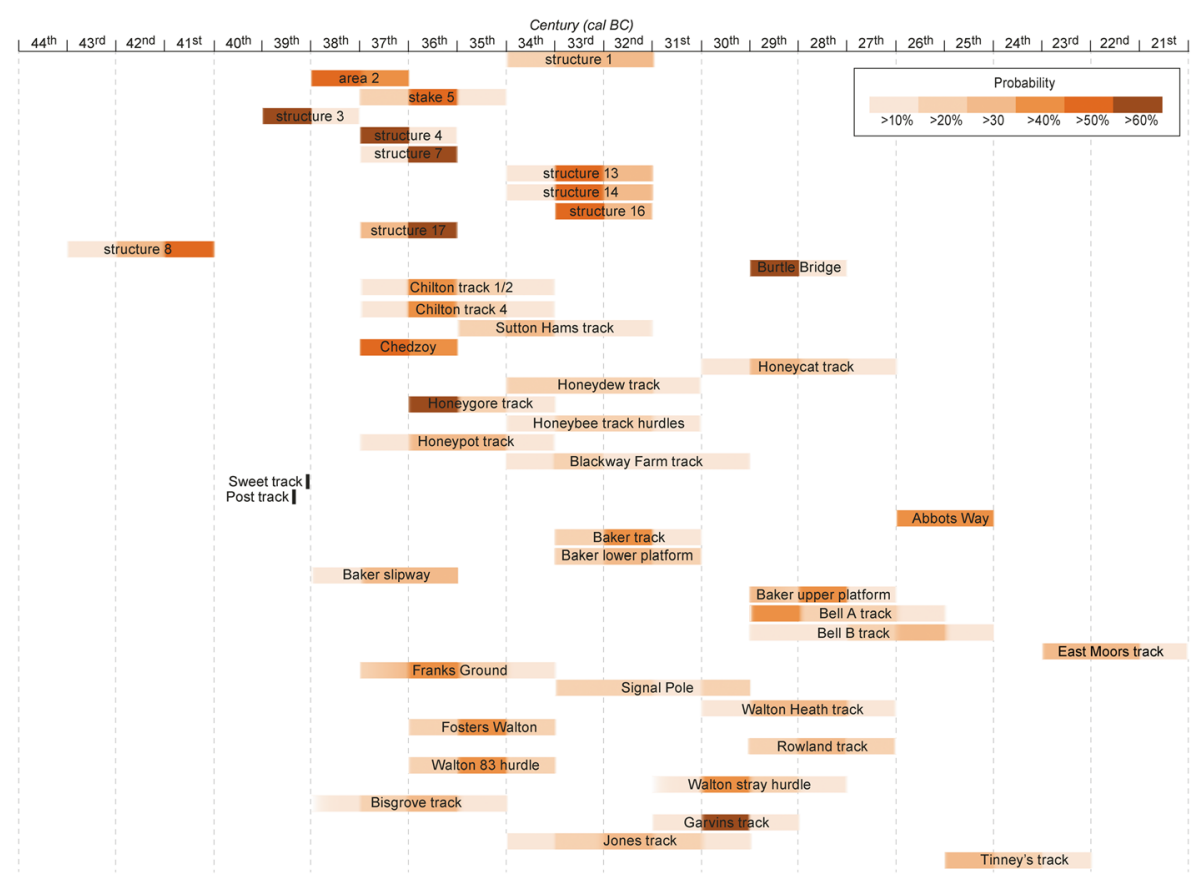

Fig. 3 Schematic diagram showing the periods of construction of dated structures on the Somerset Levels and Moors and the MSA timeslices (dotted vertical lines)

Changes in relative sea level significantly altered the palaeogeography of the study area during the early and mid-Holocene, and Neolithic human activity occurs during a period of reducing rates of relative sea level rise coupled with higher sediment aggradation rates including peatland expansion. However, a lack of sea level reconstructions that take account of aggradation rates restricted us to using modern coastline position throughout the study period. Modern sea levels were attained around $4000 \mathrm{cal}$ BC (e.g. Shennan and Horton 2002; Sturt et al. 2013), and we therefore began land cover modelling with the timeslices that bracket this date, using 4200$4000 \mathrm{cal} \mathrm{BC}$ as our baseline.

The lack of detailed palaeogeography also affects our reconstruction of the distribution of wetland vegetation communities. We used the modern surficial geology, where the deposits are mapped as peat, wet carr woodland was placed, and where they are mapped as alluvium, floodplain woodland was placed. Where they are mapped as Holocene tidal sediment, beach deposits or sand, pixels were allocated to either bare

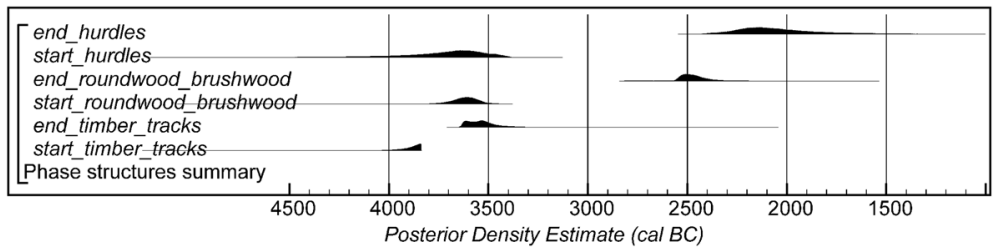

Fig. 4 Probability distributions for beginnings and endings of construction of different types of wooden structures on the Somerset Levels and Moors. The format is identical to that of Fig. S2b, although the tails on some distributions have been shortened. The distributions are derived from the model shown in Fig. S2n 


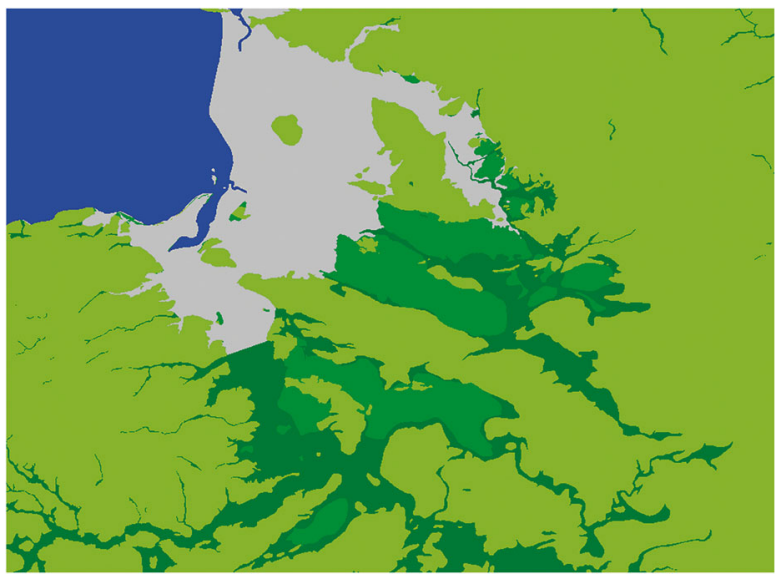

Fig. 5 The modelled Neolithic vegetation of the Somerset Levels and Moors prior to the addition of woodland clearings. Where tidal influences are dominant in the western Levels, saltmarsh, reed swamp and mudflats (all shown in grey) were modelled. In the eastern Moors below $3 \mathrm{~m}$ asl, floodplain (dark green) and mixed carr woodlands (medium green) were placed, with the rest of the landscape covered by mixed deciduous woodland (light green)

mud, marsh or saltmarsh with a probability distribution of 0.2:0.4:0.4. All other areas above an arbitrarily chosen limit of $3 \mathrm{~m}$ asl were designated as dryland woodland.

We then modelled the presence of clearings within the wooded areas. Natural forest tree canopies are not perfectly closed; as reviewed above, many natural causes of clearing generation act within the landscape, and clearing creation and successional recolonisation will create a mosaic of clearings and closed canopy. Clearings may arise from multiple causes (e.g. Brown 1997), and for this paper, clearings were modelled simply as treeless areas dominated by grasses with some weedy plant taxa often considered to be grazing indicators, although the reality would have been more complex with a variety of intermediate stages between full clearing and full woodland cover. This community, therefore, could be either a clearing or a clearance, if maintained by pastoral activity. Cultivation clearance was modelled as garden plots with cereals and associated weeds. Full details of the data sources and processing methods used to derive the environmental input grids are given in Supplementary Information $\mathrm{S} 1$, and of the composition of each modelled vegetation community in Table S1a.

\section{Thought Experiments: the Palynological Visibility of Clearings and Clearances}

First, we applied a 'thought experiment' approach to investigate the potential of pollen records collected from the sedimentary archives of the Levels and Moors to detect the presence of clearings and clearances in a largely wooded landscape. Thought experiments use the pollen dispersal and deposition model within a multiple hypothesis testing framework to investigate how (and indeed whether) the pollen signal changes in response to hypothesised differences or changes in land cover (e.g. Fyfe 2006; Caseldine and Fyfe 2006; Caseldine et al. 2007; Tipping et al. 2009; reviewed in Bunting and Farrell 2018). Thought experiments support the interpretation of pollen records but do not make direct use of existing palynological datasets. 
Where human disturbance of vegetation is localised, the position of the sampling location relative to the activity has a large effect on the detectability of the activity (e.g. Binney et al. 2005; Bunting 2008). Pollen records are also known to be sensitive to variations in vegetation patterning, as well as overall land cover composition (Bunting et al. 2004).

We therefore conducted two thought experiments representing contrasting Neolithic land use models to explore the effects on the pollen signal of both a single large clearance and multiple smaller clearings throughout the dryland woodland (Fig. 6). It seems likely that Neolithic settlement would have been present on the sandy islands of the Burtle Beds within the Levels and Moors (Coles et al. 1973), which are still visibly preferred in the modern settlement patterns. Trackway construction could well have been partly driven by a need to travel to and from these 'island' settlements in addition to crossing the valleys or accessing the wetland resources within them. In the first thought experiment, we modelled a single clearance of around 72 ha on Westhay Island, consisting of grazed grassland with scattered small cereal plots, and simulated pollen assemblages at different positions in the adjacent wetland (Fig. 7a). Point F is at the same location as the existing pollen sequence from Shapwick Heath (Tinsley 2007), and the remaining six are hypothetical. The type of wetland vegetation present at the sampling location also affects the visibility of anthropogenic disturbance (e.g. Binney et al. 2005; Bunting 2008), and therefore four different types of local wetland vegetation were modelled (raised bog, marsh, alder carr and mixed wet woodland: see Table S1a for community compositions).

Figure $7 \mathrm{~b}$ shows the simulated proportion of anthropogenic indicator pollen types (Plantago lanceolata, Rumex-type and cereal pollen) at all seven modelled sampling points. The results show a rapid decline in the proportion of open land pollen types with distance from the farmed area, and that a change in local wetland vegetation can have a significant impact on the pollen signal without any change in the dryland vegetation. At the first sampling point, only $50 \mathrm{~m}$ from the dryland edge, the pollen signal ranges from $6.2 \%$ anthropogenic indicator taxa in raised bog vegetation to $2.8 \%$ in wet woodland, a more than

General thought experiment process:

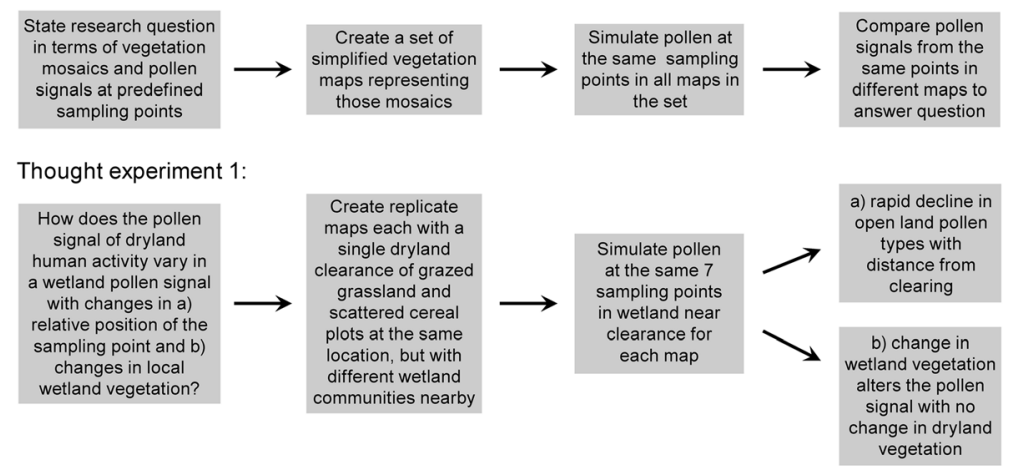

Thought experiment 2:

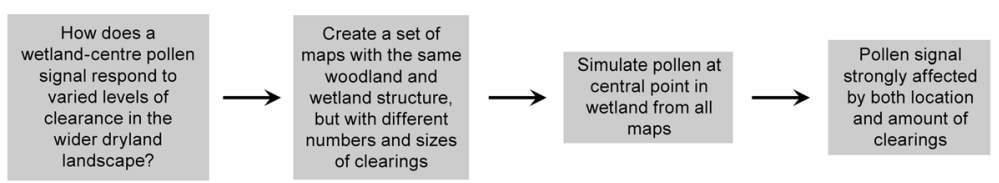

Fig. 6 The process for thought experiments used in this paper 
a
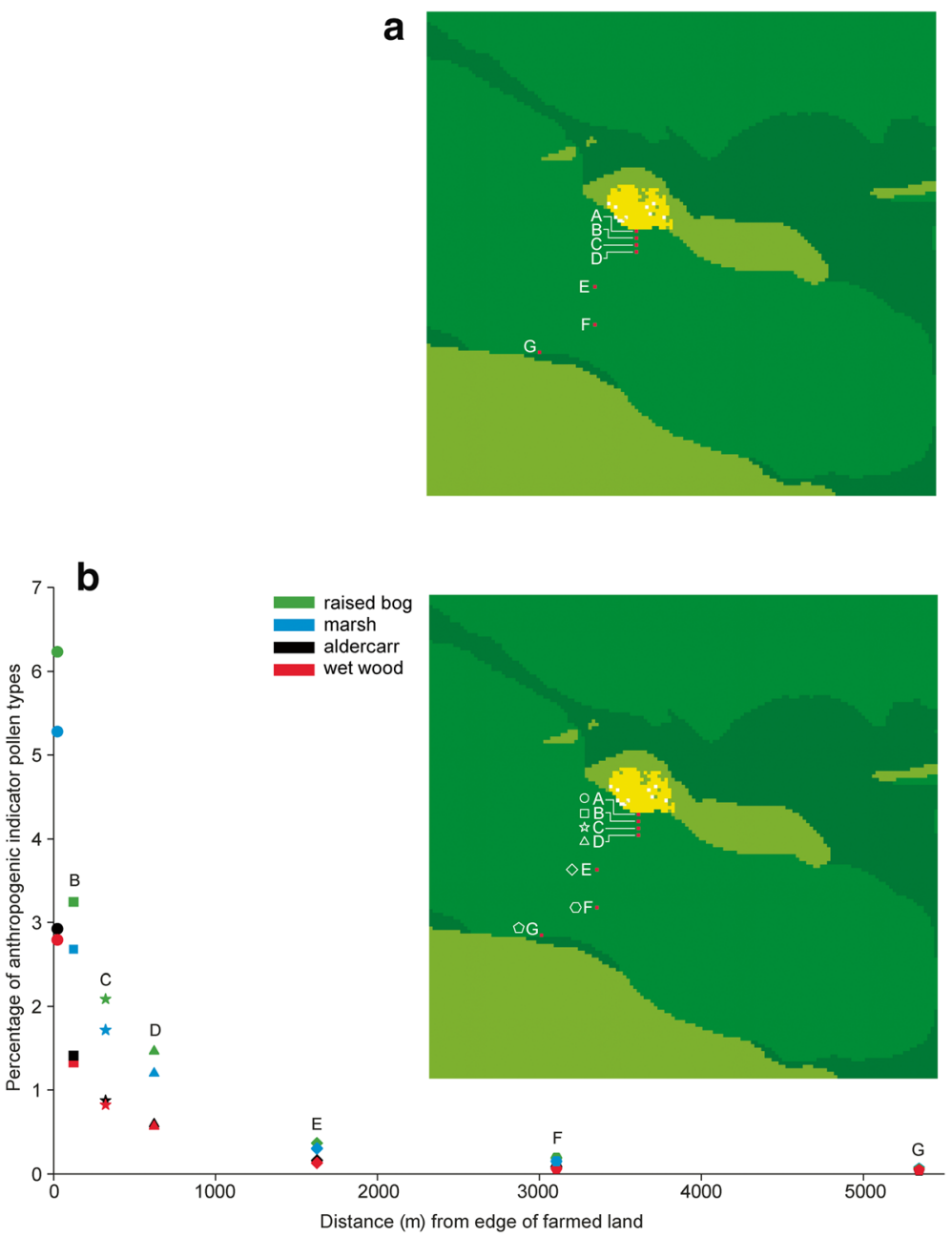

Fig. 7 a A series of simulated coring locations in the northern part of the Somerset Moors. Point $\mathrm{F}$ is at the same coordinates as the actual core from Shapwick Heath (Tinsley 2007). The location of a hypothetical Neolithic settlement with a 72 ha cleared area, consisting of grazed grassland shown in yellow with some garden cereal plots shown in white, occupies part of Westhay Island. b Simulated proportions of anthropogenic indicator taxa (Plantago lanceolata, Rumex-type, and cereal pollen) derived from the hypothetical Neolithic settlement expected at all seven coring points shown in Fig. 7a, in varying scenarios of local wetland vegetation

two-fold difference. The 'palynological visibility' of human activity in sedimentary records depends on multiple factors, especially the number of pollen grains counted by the analyst in each sample, but the lower the proportion of pollen types of interest (e.g. anthropogenic indicator taxa), the harder it is to confidently identify a signal of deliberate activity as distinct from the background levels of presence of those taxa in a natural landscape.

This thought experiment shows that where human disturbance is localised, the position of the sampling location relative to the activity has a large effect on the detectability of the activity, as expected (e.g. Binney et al. 2005; Bunting 2008). The type of wetland vegetation present at the sampling location also affects the 'palynological visibility' of the disturbance, 
emphasising the importance of structuring pollen record interpretation by first identifying the local sediment-forming environment via pollen and other proxies (e.g. plant macrofossils and insect remains) before reconstructing land cover in the wider landscape.

Since this first thought experiment showed that sequences located towards the middle of wetland deposits do not record a strong signal from a localised area of human activity, but most well-dated sequences from the study area come from locations with deep deposits well away from the dryland edge, we conducted a second thought experiment to explore the sensitivity of such records to changes in the wider landscape.

The second thought experiment therefore explored the pollen signal of scattered clearings in the dryland woodland across the whole landscape in the sediments of a centrally located sampling site with local alder carr vegetation (point E on Fig. 7). A large number of landscapes were modelled using different sizes of clearing to simulate different land use scenarios from small scattered glades to smaller and larger occupation sites, both more dispersed and more clustered, as well as different total numbers of clearings.

Figure 8a shows the simulated pollen signal of dryland woodland clearings in this central sequence. The mean percentage of anthropogenic indicator pollen taxa increases with increasing numbers of clearings, but the variation in pollen signal for a given percentage of clearings in the landscape is great enough to show that, as Sugita et al. (1999) argued, inferring the proportion of clearings in a landscape from a single pollen sampling location is not possible. The pollen signal is strongly affected by the location of the clearings, as well as by the amount of cleared land, and pollen records are known to be sensitive to variations in vegetation patterning as well as overall land cover composition (Bunting et al. 2004).

Figure $8 \mathrm{~b}$ shows that the variability seen is largely driven by scenarios with a small number of larger clearings, with variability reducing if the landscape is organised into smaller cleared units or multiple small gardens or grazed clearings. In a sequence with closely spaced pollen samples giving decadal temporal resolution, the variability of anthropogenic indicator pollen taxa may therefore provide some insight into landscape organisation, but when pollen assemblages are averaged into 200-year timeslices for reconstruction, the landscape organisation may have changed multiple times during those 200 years, reducing the variability of the pollen signal at any one location.

\section{Applying the MSA to Infer Variation in the Proportion of Woodland Clearings and Potential Clearance Through the Neolithic}

Secondly, we used the MSA to obtain initial estimates of variation in the proportion of woodland clearings over the period 4200-2000 cal BC, and thereby to infer the possible scale of clearance associated with Neolithic activity in the region. We began by collating pollen records and associated radiocarbon dates ${ }^{2}$ from the region and grouping pollen data into a series of timeslices.

\footnotetext{
${ }^{2}$ None of the pollen data was archived with the European Pollen Database (EPD): http://www. europeanpollendatabase.net/index.php). Pollen count data for 19 sequences were available from analysts and for nine sequences data were recovered by 'reading' from published diagrams. To ensure that loss of pollen data does not occur, it is imperative that it should be archived within a suitable repository such as the European Pollen Database. At present, data from only 96 radiocarbon-dated sequences from locations within the UK are archived with the EPD, representing $<4 \%$ of dated UK pollen sequences (see Grant and Waller 2017).
} 

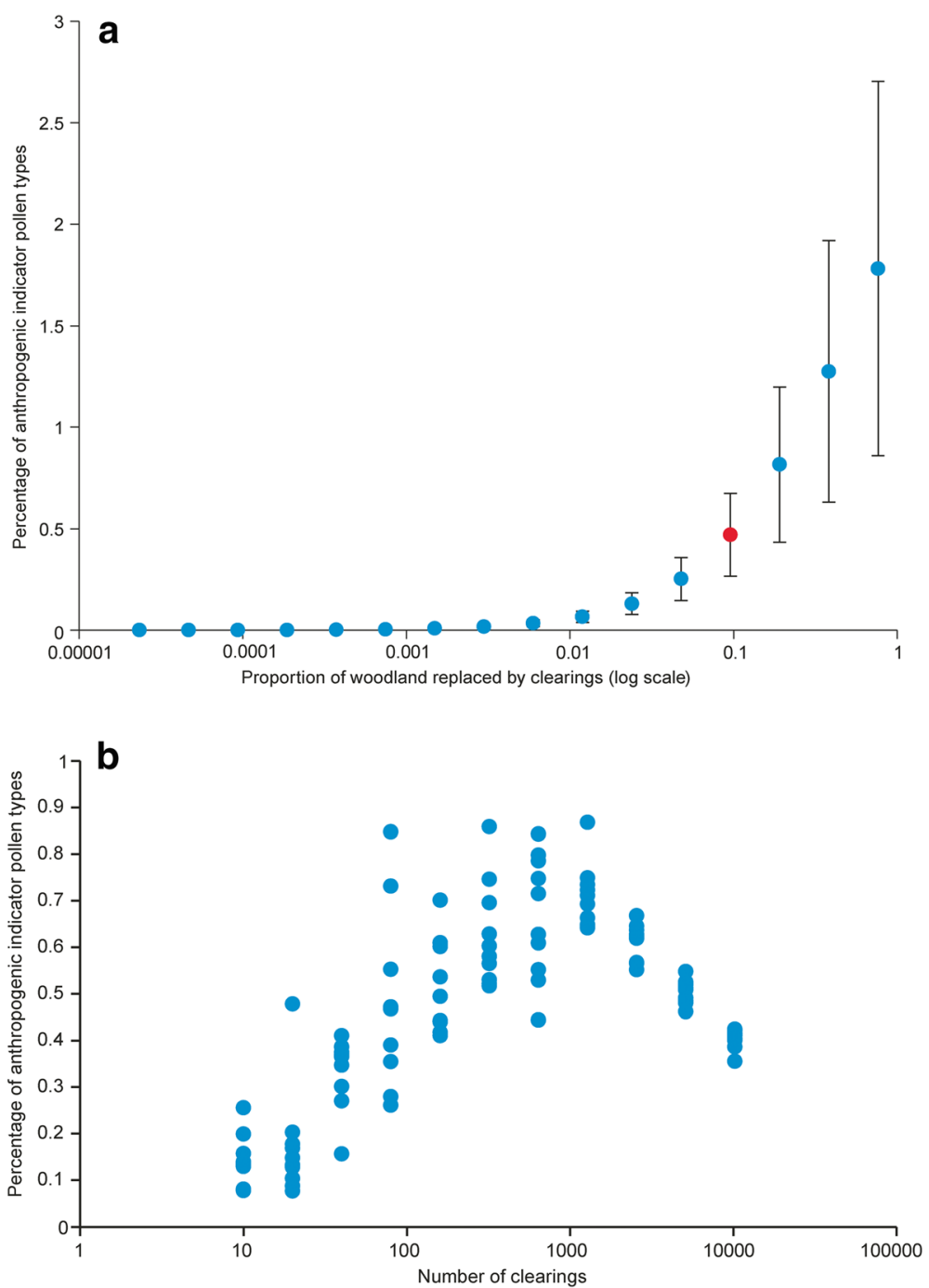

Fig. 8 a Simulated percentages of two classic anthropogenic indicator pollen taxa (Plantago lanceolata and Rumex-type) in a core at the centre of an alder carr woodland from location $\mathrm{E}$ on Fig. 7 for different percentages of dryland woodland clearings. Highlighted proportion of clearings $(0.10)$ is used for Fig. 8b. b Simulated percentages of Plantago lanceolata and Rumex-type pollen in a core from location E on Fig. 7 that result from a landscape containing $10 \%$ clearings in the dryland woodland, showing the effect of varying the size of the clearings (clearing size decreases and number of clearings increases along the $x$-axis)

Radiocarbon measurements on 138 macrofossil or peat samples and six luminescence ages from 28 palaeoenvironmental sequences were used to construct 26 age-depth models. Small numbers of radiocarbon measurements from long sequences result in low-resolution chronologies, especially for samples located between radiocarbon measurements, for which the age has to be estimated through interpolation. For the purposes of land cover reconstruction, the study period was divided into equal-sized bins, which we refer to as 'timeslices'. Given the available data (Table S3a), our timeslices are at a relatively coarse resolution of 200 years. Age-depth models (see Supplementary Information S3 for full 
details) for the 26 sequences listed in Table 1 were derived from Bacon (Blaauw and Christen 2011) using IntCal13 (Reimer et al. 2013). Bacon is the Bayesian age-depth modelling software used to reconstruct accumulation histories for deposits by combining scientific dates with prior information. For each pollen sequence, all samples falling within a particular timeslice were identified, and the pollen percentages summed and averaged to provide a single pollen assemblage for each 200-year timeslice. Only sites with pollen assemblages dating to the relevant timeslice were included in the modelling of that slice, and therefore each timeslice used a slightly different set of pollen records (ranging from seven to 16 different locations: Table 1). The median age estimates for depths with pollen samples were used to assign pollen data to one of the 11200 -year timeslices covering the period from 4200 to 2000 cal BC (Table 1). For the two sequences without age-depth models, pollen samples were assigned on the basis of radiocarbon dates obtained from the same depth in their individual sequence.

For the first stage of landscape reconstruction for each timeslice, a very wide range of possible levels of clearings $(0-100 \%)$ and of local wetland conditions was considered, producing 11,264 landscape scenarios in combination. Full details of the modelling strategy are given in Supplementary Information S1. Goodness-of-fit scores between simulated pollen assemblages and actual pollen assemblages for each site were used to identify the best-fit range of local wetland vegetation conditions independently for each pollen site. Summed goodness-of-fit scores for all pollen sampling sites were used to estimate the best-fit range of proportion of clearings in both sets of woodland landscape scenarios (clearings in dryland woodland only or in all woodland).

These then formed the basis of a second stage, where we tested timeslice-specific sets of scenarios with each site having different local wetland conditions (determined from the best fits for each site from the first stage), using $5 \%$ increments of the proportion of woodland clearings within the best-fit range previously identified. At this stage, we tested multiple repeats of each scenario to ensure that we took into account variations in pollen signals at particular sites due to the random placement of clearings, since pollen records are known to be sensitive to variations in vegetation patterning as well as overall land cover composition (Bunting et al. 2004).

During the examination of the results, it was clear that the reconstructed proportion of clearings varied between the different pollen sites, with a higher proportion of clearings generally inferred from sites closer to the coastline. We suggest that this may reflect our poor understanding of landscape palaeogeography, since a small change in coastline position or the altitudinal limit to dryland woodland would have a marked effect on the distribution of the open wetland communities found near the coast, which have pollen types in common with clearings. In addition, changing sea level will have been accompanied by shifts in the structure and composition of vegetation communities throughout the wetland landscape, as changing base levels altered the flooding regime in the river valleys and across the Moors. Sea level was likely established at modern levels by around 4000 cal BC (e.g. Shennan and Horton 2002; Sturt et al. 2013) but the uncertainty on its actual position in our 200-year timeslices is high, and imposes potential errors on this reconstruction exercise. Figure 9 shows an example of a good-fit land cover map for the timeslice 3800-3600 cal BC (examples for all 11 timeslices are shown in Supplementary Information S1).

Results in the form of a single estimate of the proportion of clearings in the woodlands were extracted in two different ways. First, we identified the best-fit scenario for each 
Table 1 Details of sites with pollen data included in 200-year timeslices 4200-2000 cal BC (highlighted cells). *Sequence does not have an age-depth model, and so pollen samples have been assigned on the basis of radiocarbon dates obtained from the same horizon. Full details, including references to original publications, are contained within Supplementary Information S3

\begin{tabular}{|c|c|c|c|c|c|c|c|c|c|c|c|c|c|}
\hline Sequence & $\begin{array}{c}\text { Radiocarbon } \\
\text { Dates }\end{array}$ & $\begin{array}{l}\text { OSL } \\
\text { dates }\end{array}$ & 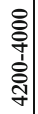 & 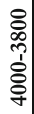 & 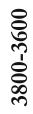 & 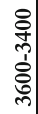 & 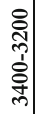 & 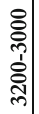 & 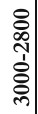 & 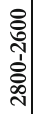 & 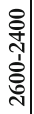 & 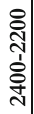 & 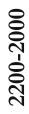 \\
\hline Steart Point - BH02* & 2 & 1 & & & & & & & & & & & \\
\hline Steart Point - BH109 & 2 & 2 & & & & & & & & & & & \\
\hline Steart Point - BH112 & 2 & 2 & & & & & & & & & & & \\
\hline Burnham on Sea - Upper & 2 & & & & & & & & & & & & \\
\hline Burnham on Sea - Lower & 2 & & & & & & & & & & & & \\
\hline Pawlett & 4 & & & & & & & & & & & & \\
\hline Walpole Landfill & 6 & & & & & & & & & & & & \\
\hline Walpole - Trench L & 5 & & & & & & & & & & & & \\
\hline Walpole -Trench A* & 1 & & & & & & & & & & & & \\
\hline Chedzoy & 4 & & & & & & & & & & & & \\
\hline Woolavington Bridge & 2 & & & & & & & & & & & & \\
\hline Grevlake - monolith 3 & 2 & & & & & & & & & & & & \\
\hline Shapwick Heath & 5 & & & & & & & & & & & & \\
\hline Shapwick - Pit 2 & 9 & & & & & & & & & & & & \\
\hline Abbot's Way & 14 & & & & & & & & & & & & \\
\hline Shapwick - SWA93 & 7 & & & & & & & & & & & & \\
\hline Sweet Track - Factory & 6 & & & & & & & & & & & & \\
\hline Shapwick Heath - axe site & 4 & & & & & & & & & & & & \\
\hline Meare Heath & 8 & & & & & & & & & & & & \\
\hline Sweet Track - TW & 4 & & & & & & & & & & & & \\
\hline Meare Village East & 3 & & & & & & & & & & & & \\
\hline Eclipse Track & 7 & & & & & & & & & & & & \\
\hline Heath Rhyne* & 2 & & & & & & & & & & & & \\
\hline Sharpham Drove & 2 & & & & & & & & & & & & \\
\hline Benedict Street - Trench & 3 & & & & & & & & & & & & \\
\hline Glastonbury - Wells Road & 2 & & & & & & & & & & & & \\
\hline Glastonbury - GA-18 & 6 & & & & & & & & & & & & \\
\hline Queens Sedgemoor & 23 & & & & & & & & & & & & \\
\hline
\end{tabular}




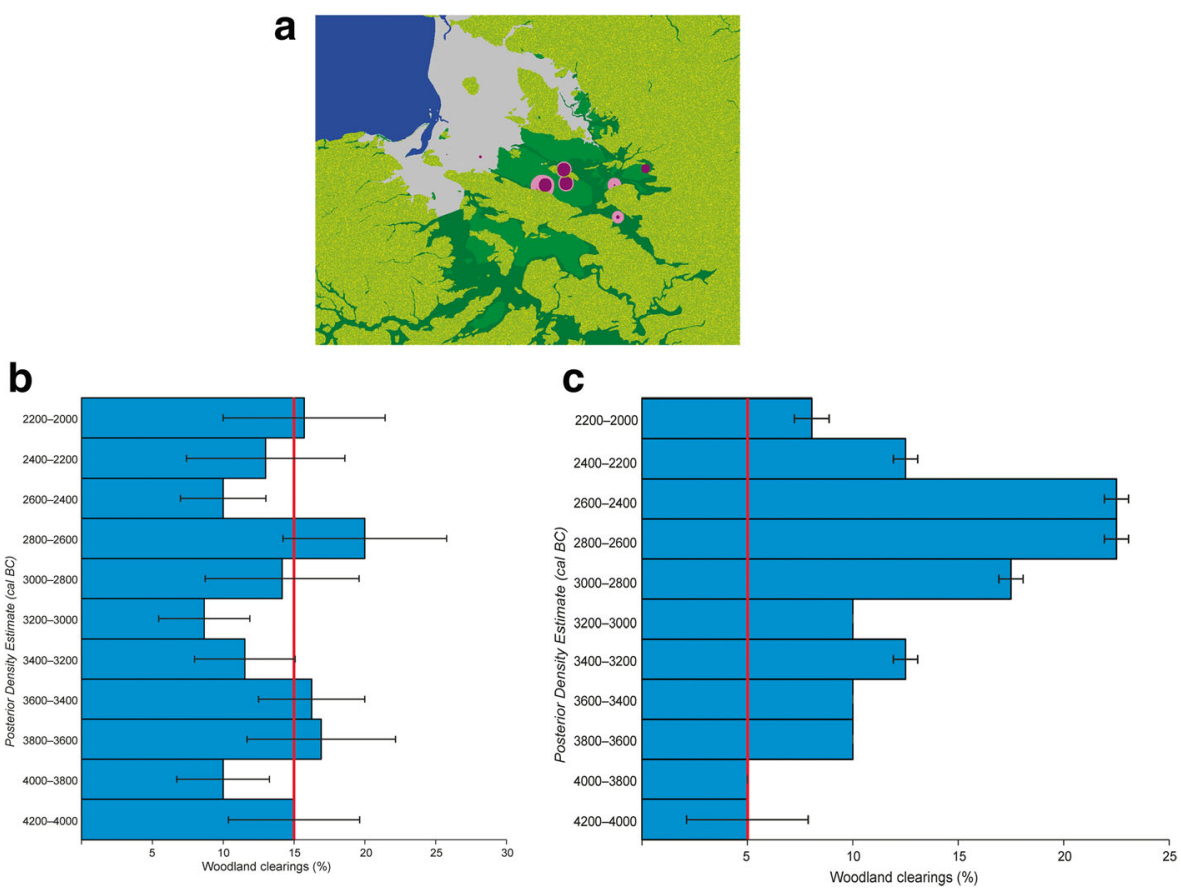

Fig. 9 a An example of a good-fit land cover map for the timeslice 3800-3600 cal BC. Grey = tidally influenced vegetation (saltmarsh, reed swamp and mudflats); purple = raised bog; pink = alder carr; medium green $=$ mixed carr woodland; dark green = floodplain woodland; light green = mixed deciduous woodland; yellow = clearings. b An estimate of changing percentage of woodland clearings from 4200-2000 cal BC, based on the average of the proportions of clearings required to achieve best fits at individual sites during each timeslice. The red line indicates the pre-Neolithic baseline level of clearings (see text for details). c An estimate of changing percentage of woodland clearings from 4200-2000 cal BC, based on the average proportion of clearings in the overall best-fit landscape reconstructions for each timeslice. The red line indicates the preNeolithic baseline level of clearings (see text for details)

individual site in turn for a specific timeslice, noted the proportion of clearings in that scenario, and then took the mean across all the sites in that timeslice. This approach emphasises the conditions in the local area around each pollen sampling locality, and therefore is likely to reflect the proportion of clearings in the Levels and Moors and at their margins. Second, we took the mean of the proportion of clearings in the scenarios with the best overall fits (based on the sum of goodness-of-fit scores across all the included pollen sites) for each timeslice. This approach puts more emphasis on the whole landscape reconstruction, and therefore is likely to mostly tell us about the amount of clearings in the wider wooded landscape around the Levels and Moors.

The means of the proportion of clearings required to achieve best fits at individual sites plotted over the study period are shown in Fig. $9 \mathrm{~b}$ and the average proportion of woodland clearings in the overall best-fit landscape reconstructions for each timeslice in Fig. 9c. The landscape already contained some clearings before the start of the Neolithic (considered for this region as falling within the 4000-3800 cal BC timeslice; see Figs. 2, 3 and 4). We therefore take the pre-Neolithic timeslice (4200-4000 cal BC) as a 'baseline' for natural proportions of clearings in the landscape. This baseline is indicated by the red line on Fig. 9b, c. Figure $9 \mathrm{~b}$ emphasises the proportion of clearings 
in the Levels and Moors area, and suggests that the 'natural' proportion of clearings is around $15 \%$, whilst Fig. 9c implies that the 'natural' proportion of clearings in the wider woodland landscape is around $5 \%$. These values will include both woodland glades and patches of other open communities such as reed swamp and fen, particularly along the river channels or in the alder carr. These levels of openness are comparable with the $9.5 \%$ reported for old-growth deciduous forests in North America (Runkle 1982). Where levels of clearings in later timeslices rise above the baseline, we considered it possible that clearance as a result of human activity was taking place.

Figure $9 \mathrm{~b}$ shows that whilst the proportion of clearings in the Levels and Moors area varied over the Neolithic, it rarely clearly exceeds the pre-Neolithic baseline when considered in the surroundings of individual pollen sites. Slightly higher levels in the period 3800-3400 cal BC may reflect ongoing activity in parts of the wet woodland, since many of the pollen sampling sites were chosen for proximity to trackways and other wooden constructions, and there also seems to be a higher level of clearings in the 28002600 cal BC timeslice. The earliest Neolithic activity in the region appears to date not later than to the thirty-ninth century cal BC (Fig. 3). The proportion of woodland clearings in the wider landscape (Fig. 9c) approximately doubles at this point and persists at that level until 3000 cal BC, which we interpret as reflecting the addition of anthropogenic clearance (sensu Brown 1997) to the landscape disturbance regime, either in terms of the direct creation of clearings or of the exploitation of existing clearings, thereby prolonging their lifetime. The proportion of clearances increases after $3000 \mathrm{cal} \mathrm{BC}$ to a maximum of around $22 \%$ between $2800 \mathrm{cal} \mathrm{BC}$ and $2400 \mathrm{cal} \mathrm{BC}$, followed by a decrease towards baseline levels for the last two timeslices.

\section{Discussion}

\section{Using Thought Experiments to Better Understand the Palynological Visibility of Clearings and Clearances}

Thought experiments such as those presented here provide insights into the potential and limitations of pollen records. Here we have been able to show that small-scale, local farming activity could be detected by carefully placed sampling locations, and that changes in the proportions of clearings in the wider landscape can be detected in an extensive wetland. We have also demonstrated how changes in local wetland vegetation affect the sensitivity of pollen records to indicators of dryland activity.

Thought experiments can also enable more effective targeting of resources in planning future palaeoecological investigations. Given a known or inferred dryland archaeological site, such as a settlement or trackway landfall, simulation can determine the pollen sampling location most likely to record the inferred disturbance of vegetation due to human activity. In addition, it can also be used to construct hypothesis tests by determining the expected changes in the pollen record that would occur in response to different types of activity. For example, in the first thought experiment, samples taken within a few hundred metres of the archaeological activity are more capable of detecting changes in human land use at relatively low pollen sums than those taken at the centre of the wetland (often preferred when sampling as they are assumed to contain the deepest and therefore oldest and most complete records). Using a thought 
experiment approach to identify the most sensitive locations for pollen record retrieval in future, and ensuring material is dated to locate target horizons before carrying out pollen analysis, will both increase the likelihood of collecting archaeologically relevant data and allow for targeted use of palynology even in projects with limited resources.

The thought experiment approach could be employed, for example, to test hypotheses regarding Neolithic settlement and localised clearance on the sandy islands of the Burtle Beds (Coles et al. 1973). By simulating the pollen signal of clearance on these islands at several possible sampling locations, the place most likely to detect such activity could be selected for sampling. Analysis of the pollen from this sequence would allow hypotheses regarding human activity on the islands to be confirmed, rejected or modified for further investigation.

\section{Variations in Neolithic Land Cover in the Somerset Levels and Moors}

The results of the land cover modelling show that using pollen records to interpret smallscale human-mediated disturbances in a landscape such as the Somerset Levels and Moors has considerable potential and, though challenging, is feasible. The thought experiments showed that, although local wetland conditions can suppress the signal of Neolithic agriculture (Fig. 7b), it is possible to detect small-scale occupation and activity in the records from the Levels and Moors (Fig. 8), and that the hypothesised shifting nature of clearances associated with early agriculture actually increases their visibility in the pollen record (Fig. 8b). Vegetation reconstruction using the MSA shows a clear increase in woodland clearings in the wider landscape (Fig. 9c) of up to $17 \%$ above the pre-Neolithic baseline during the Neolithic, which we interpret as a sign of anthropogenic clearance. Some of these clearances may be associated with woodland management, since analysis of wood used to construct the trackways shows changes in wood age structure indicative of coppicing (Coles and Coles 1986, 1992), and others with dryland agriculture in the form of grazing animal management or cereal cultivation.

It is important to emphasise that whilst previous studies clearly did not neglect questions of the scale of human activity and clearance, wider inferences have often been limited. A review of research on the Sweet Track, for example, noted once again the difference in the age of oaks used in construction, which suggested exploitation of areas of both primary and secondary woodland, and stressed the brevity of activity in a context seeming to lack direct evidence of cereal cultivation (Coles and Brunning 2009, pp. 25, 28, 31); an earlier estimate was of the use of at least 500 trees for the rails which underpin the trackway (Coles and Coles 1986, p. 63). One major conclusion was of 'shifting small-scale clearance of the primary woodland' (Coles and Brunning 2009, p. 31 ), but this was not further quantified. Another review had gone a little further, but even then in very broad-brush terms, contrasting 'a healthy, well-established human occupation of the area in the Early Neolithic' and 'a period of forest clearance on the dryland' with a 'decrease in pollen evidence for forest clearance and farming' at the turn of the fourth millennium cal BC, followed in the middle centuries of the third millennium by 'a picture of forest cover on the drylands fringing the Levels, but clearance and farming on the islands in the middle of the raised bog' (Coles and Coles 1992, pp. 30-31; cf. Coles and Coles 1986; Noble 2017, pp. 131-132).

Whilst the reconstructions presented here support the model of increased clearance of the dryland woodland from the early Neolithic (see Fig. 9c), the timing of increases 
and decreases is offset from previous reviews. Our reconstructions show the highest levels of clearance at the start of the third millennium cal BC, with a decrease towards the end of this millennium. These differences may partly be due to the different spatial scales considered. More recent research still, detailed and concentrated on a series of local situations, has been focused on the Mesolithic and the Mesolithic-Neolithic transition, with indications from local pollen evidence of some early Neolithic activity on both the Burtle Beds north and south of the Polden Hills, including at Shapwick close to the southern end of the Sweet Track (Bell 2015, p. 143), but again the scale of early activity has not yet been specifically quantified, beyond the generalisation that it was probably 'rather smaller scale clearance with limited or equivocal evidence for agriculture' (Bell 2015, p. 176). The MSA reconstructions presented here offer a more nuanced understanding of the scale and timing of Neolithic clearance in the Somerset Levels and Moors.

\section{Comparing Models of Clearance with Archaeological Sequences}

As set out above, the limitations of the precision available for the age-depth models and pollen sampling intervals have meant that so far it has been possible only to reconstruct land cover for 200-year timeslices, even though individual archaeological sites can sometimes be dated much more precisely (see Supplementary Information S2). That is at a coarser resolution than the timescales of lifetimes and generations advocated in a recent study of causewayed enclosures in southern Britain in particular and of the early Neolithic context in general (Whittle et al. 2011), and sets a tension between different kinds of temporal resolution. Earlier reviews had already noted this, stressing the evidence for probably discontinuous and short-lived activity on trackway construction across the centuries of the fourth and third millennia cal BC (Coles and Coles 1992; Coles and Brunning 2009). In his paper on the temporality of the landscape, Tim Ingold coined the distinction between landscape and taskscape-landscape is what you can see, taskscape is what you can hear and so landscape is taskscape congealed (Ingold, 1993, p. 162). In these terms, our timeslices and MSA modelling still present landscapes, generalised interpretations of activity and impact, rather than the immediacy and variability of taskscapes which Ingold sought (and which can, perhaps, be rather vividly captured in specific wetland situations such as the reed swamp setting of the Sweet Track: Coles and Brunning 2009, p. 25). In particular, the initial centuries at the start of the fourth millennium in the Somerset Levels and Moors must have witnessed a whole series of changes in practices and tasks, but the discontinuous, short-lived nature of human activity will have created a succession of individual taskscapes that are currently blurred together in the MSA reconstructions.

This might therefore look like a regrettable loss of resolution, but in this context may, paradoxically, enable wider trends to be more easily visible. The combined, synthesising approach presented here has the potential to develop considerably more detailed narratives of human activity, beyond the immediate construction and use of the trackways and related features such as platforms. In the first place, the MSA models presented here offer a fuller narrative for land use around the Levels and Moors themselves. One of the most striking trends is the seeming contrast between the differing scales of trackway activity on the one hand and of wider clearance on the other (Fig. 10). There appears to be something of an inverse correlation for much of the 


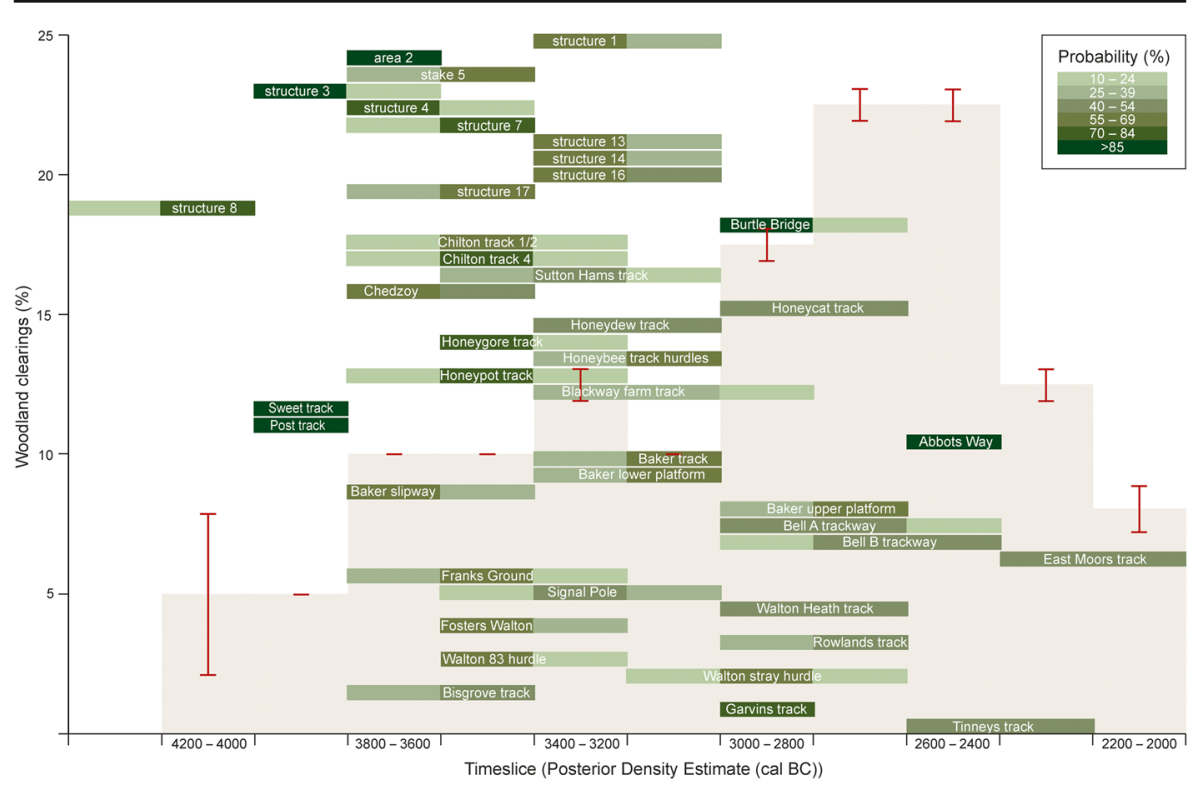

Fig. 10 Schematic diagram showing the periods of construction of dated structures on the Somerset Levels and Moors overlaid on the estimates of the percentage of woodland clearings based on overall best-fit landscape reconstructions from 4200-2000 cal BC. Note that the errors on some estimates are too small to be visible on this figure (e.g. that for clearings in the 3800-3600 cal BC timeslice)

sequence between the effort invested in trackway construction and the scale of wider clearance. Thus the Sweet Track, with its kilometres of length and hundreds of trees felled and used, sits in contrast to the initial relatively small scale of Neolithic clearance activity. That can speak not only to the special significance of the Sweet Track itself, in conditions of pioneering settlement (Coles and Brunning 2009) (and also to the local conditions underfoot), but also to the subsequent routinisation of more modest hurdle and brushwood trackways, more easily and less laboriously assembled, part-by-part, from the products of a managed and established more open landscape including coppiced stands, in a wider setting with a greater extent of clearance, suggested for example for the timeslices following $3800 \mathrm{cal} \mathrm{BC}$. Is it then just coincidence that a heavier form of trackway construction as seen in the Abbots Way recurs in the middle of the third millennium when the MSA reconstruction for the timeslice 26002400 cal BC suggests again less open local conditions, as suggested by Fig. 9b? Perhaps in some way the more heavily built trackways served to create more explicit signalling about social connections in less open settings, if they are not, again, to be seen as a response to purely local conditions of wetness.

Our models for the Somerset Levels and Moors also prompt useful comparisons and contrasts with neighbouring regions across southern Britain, both in specific situations and in terms of possible general trends, in an archaeological landscape in which definable occupation sites are scarce and their accompanying material culture chronologically not very sensitive. The practice of settlement must have varied (Pollard 1999), but it has proved recurrently difficult to get at not only the timing but also the scale of activity. Thus for the area around the great enclosure complex at Hambledon Hill, Dorset, to the south of the Somerset Levels and Moors, the tentative conclusion (given 
the challenges of finding suitable evidence in the chalkland setting) was that 'major clearance' did not take place until the Beaker period (Bell et al. 2008, pp. 450-452). Around Avebury, north Wiltshire, again in a chalkland setting and based on varied sources of evidence including molluscan analysis and soil studies, a series of broad timeslices (4200-3700 cal BC; 3700-3400; 3400-3000; 3000-2600; 2600-2200; and 2200-1600, and later) serve to define a shifting mosaic of continuing clearance and activity, with some local regeneration at intervals (Gillings et al. 2008, figs. 5.5-5.10), though in a landscape now regarded as probably not having dense woodland as its initial baseline (Pollard et al. 2012; Allen 2017). On a smaller spatial scale, but again over quite broadly defined phases ('earliest Neolithic'; 'early'; 'middle': c. 33002900 cal BC; 'late': c. 2900-2450 cal BC), detailed reconstructions of the gradually extending scale of local clearance have been offered (using very varied sources of evidence) for the valley bottom setting at Yarnton, Oxfordshire (Hey and Robinson 2016, figs. 2.4, 2.6, 2.8, 2.10); the local picture is of small-scale activity, with openness only gradually extending through time. Finally, at Haddenham, Cambridgeshire, reconstruction of the setting of the long barrow and enclosure was aided by pollen analysis from a palaeochannel of the Great Ouse, which suggested early clearance and cultivation, and relatively open conditions thereafter (Evans and Hodder 2006; Peglar 2006). By comparison, and allowing for variation from place to place, the models given in this paper for the Somerset Levels and Moors do offer a more detailed view of change right through the sequence.

From an even broader perspective, suggested beginnings for Neolithic activity in the Somerset Levels and Moors by the thirty-ninth century cal BC conform with the wider picture for the initial development of the Neolithic suggested by Whittle et al. (2011), and the increase in woodland clearance in the 3800-3600 cal BC and 36003400 cal BC timeslices matches the scale of monument construction-first long barrows, then causewayed enclosures and finally cursus monuments-evident in southern Britain through those times. It is frustrating, however, to not yet have sufficient precision to examine whether these changes also reflect shorter lived trends in activity such as the suggested 'surge' in new practices which precedes and accompanies the first appearance of causewayed enclosures in central-southern England in the early part of the thirty-seventh century cal BC (Whittle et al. 2011, fig. 14.182).

Our models also potentially contribute to a better understanding of other, later, suggested trends. Locally, in the Levels and Moors themselves, the later fourth millennium picture (Fig. 9b) conforms to the reduced activity connected with cereal production suggested widely elsewhere (Stevens and Fuller 2012, p. 714: with a start date suggested at c. $3350 \mathrm{cal} \mathrm{BC}$ ), but the trend is less clear at the wider regional scale, though there is again a reduction in clearings in the 3200-3000 cal BC timeslice. Clearings increase again in the 3000-2800 cal BC timeslice, and the greatest proportion of clearance in the wider landscape occurs in the 2800-2600 cal BC and 26002400 cal BC timeslices (though not locally, as noted above). The latter also sees both major construction and cultural changes in the Stonehenge area, for example, so this perspective from the Somerset Levels and Moors offers an insight into both local and regional variations and convergences.

Finally, our case study here also prompts initial comparison with other parts of Britain, with Ireland and with selected regions of the adjacent continent. Estimates of openness generated by applying the LRA (Sugita 2007a, b) to groups of pollen sites in selected 
regions of the UK (Fyfe et al. 2013) are significantly higher for Dartmoor (Fig. 11a) and North Devon (Fig. 11b), the closest regions included in Fyfe et al.'s study to the Somerset Levels and Moors, than our estimates presented here, but show similar trends in terms of relative levels of openness through time. The discrepancies in the scale of openness can probably be explained by differences in methodology and the nature of the vegetation dynamics in each region. The LRA and MSA use the same mathematical model of pollen dispersal and deposition, but take different approaches to reconstruction. The LRA does not account for local on-site vegetation, which the thought experiments presented here show can have a large influence on detection of openness in the surrounding landscape. Fyfe et al. (2013) also used a different set of input parameters, particularly estimates of Relative Pollen Productivity, to those used here. The sites included in Fyfe et al.'s North

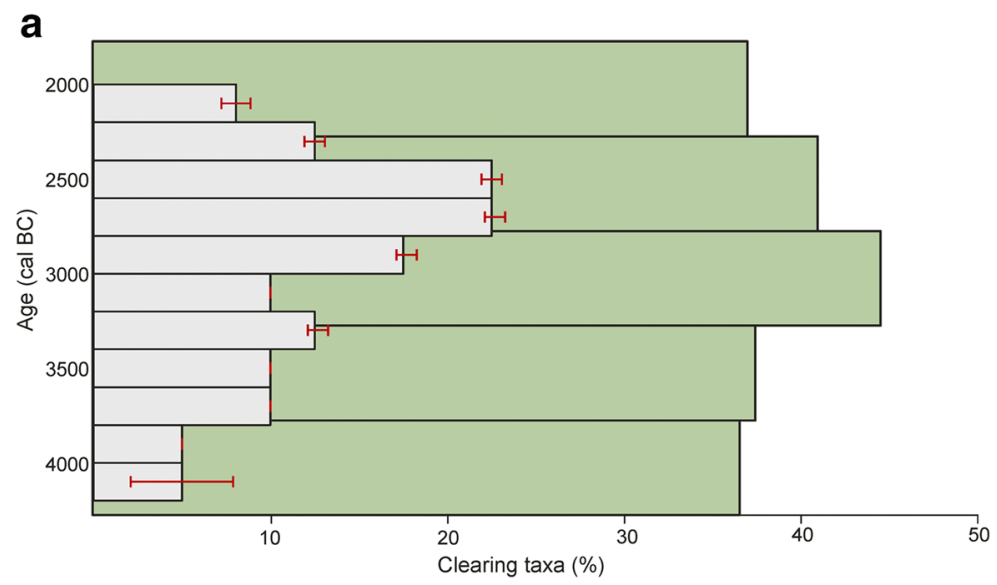

b

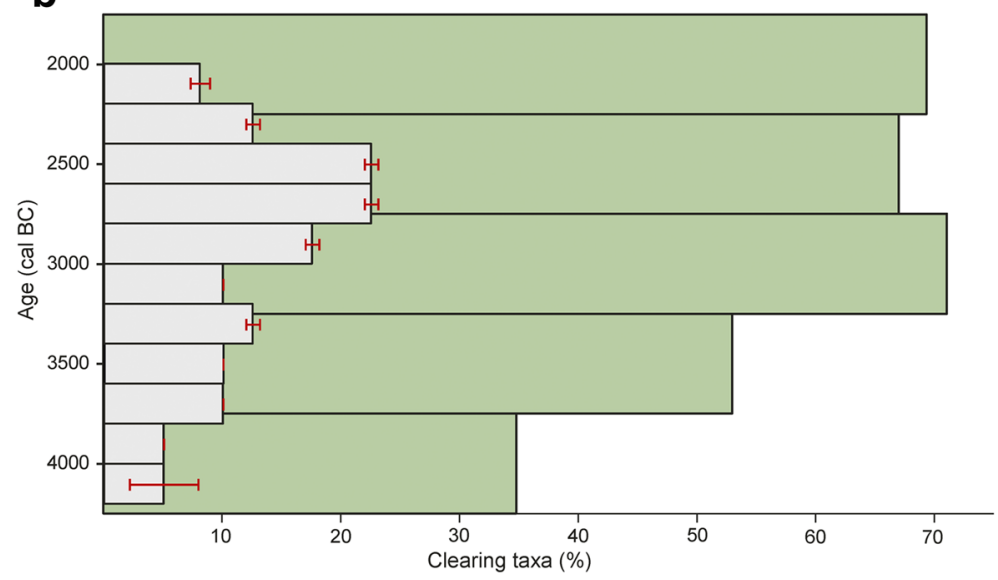

Fig. 11 a Comparison of MSA estimates of clearings in the Somerset Levels and Moors (grey bars) with estimates of openness in Dartmoor by Fyfe et al. (2013) (green bars). MSA estimates are those presented in Fig. 9c. Estimates from Fyfe et al. (2013) are based on reconstructed vegetation proportions of the taxa included in our clearing community. b Comparison of MSA estimates of clearings in the Somerset Levels and Moors (grey bars) with estimates of openness in North Devon by Fyfe et al. (2013) (green bars). MSA estimates are those presented in Fig. 9c. Estimates from Fyfe et al. (2013) are based on reconstructed vegetation proportions of the taxa included in our clearing community 
Devon grouping are all situated in and around Exmoor, and this region, along with Dartmoor, has seen the spread of peat and reductions in tree cover since the Mesolithic. The baseline levels of openness for Fyfe et al.'s Dartmoor and North Devon regions at the start of the Neolithic are therefore likely to have been higher than for the Somerset Levels and Moors, and changes over the Neolithic set against a background of ongoing natural woodland loss and peat spread.

The maintenance of landscape openness appears to be given up earlier in Ireland, $c$. 3600 cal BC (Whitehouse et al. 2014; McLaughlin et al. 2016) than in the Somerset Levels and Moors, though it is interesting to note the seemingly comparable trend to reduced landscape openness in northern Germany in the later fourth millennium cal BC (Hinz et al. 2012, fig. 2; see also Diers 2018; Knitter et al. 2019), whilst a more complicated pattern is evident in the Alpine foreland (Jacomet et al. 2016). It should be the goal of future research to track both local variation and common trends, region by region, but that kind of exercise depends on rigorous modelling of local data.

\section{The Potential for Closer Integration of Archaeological and Palynological Data}

The combined modelling approaches which we have applied in this paper currently have substantial limitations in practice. There remain considerable challenges in terms of visibility, representativeness and interpretation. Even though the Somerset Levels and Moors contain many well-preserved palaeoecological records, translating these records into simple measures of intensity of past human activity is problematic, both due to the effects of the changing local vegetation within the wetland and to the spatial arrangement of vegetation within the wider landscape. Not least, reconstruction of local wetland vegetation through detailed recording of peat stratigraphy and plant macrofossils (Birks and Birks 2000) along with the pollen record, and incorporation of other proxies to aid the reconstruction of palaeogeographies of this area of dynamic sea level change, is essential to improve confidence in interpretation of pollen data from these complicated systems. The MSA is explicitly designed to identify situations of equifinality, that is where ecologically distinct landscapes cannot be distinguished by their pollen signals, and therefore to reduce the risk of over-interpretation based on informal analysis. Since the approach produces spatially explicit scenarios of possible past land cover, it also has the potential to contribute to a more robust basis for the visualisation, or 'virtualisation' (referring to a virtual reconstruction of a past landscape that can be considered plausible whilst not necessarily being a true reflection of reality; sensu Caseldine et al. 2008; Fyfe et al. 2010), of the context of past human activity.

On the other hand, modelling has the potential to maximise the relevance of palynology for archaeological questions by allowing simulation of the likely signal of particular types and intensities of anthropogenically driven land cover change at multiple possible sampling points. It can identify whether a change in the type and/or intensity of activity is theoretically detectable by pollen analysis and provide clear guidance on where to locate samples for pollen analysis relative to archaeological activity, thereby enabling efficient research design and the effective targeting of resources. Beyond that, the current study shows the value of an approach which uses robust chronologies to integrate evidence from both palynology and archaeology. While the archaeology of the Somerset Levels and Moors on its own tends to promote a view of long-term continuity in terms of the building of wooden structures, the palynological record contributes a more dynamic and varying narrative. This provides a first-order quantification of the possible scale of Neolithic activity in this region which, if it 
could be replicated elsewhere, would contribute significantly to a much more sensitive account of the development of Neolithic landscapes and settlement. None of this is incompatible with thinking about what woods, trees, clearings and clearances may have meant to people and implied for human experience during the Neolithic ( $c f$. Noble 2017). If 'people, plants, animals and the material of the earth itself all play their role in shaping and being shaped by each other' (Harris and Cipolla 2017, p. 164), there is every reason to demand specific quantification through defined timescales of all four components of the past environment. This paper demonstrates how this could be done for the plant component, enabling us to get closer in the future to reconstructing the lived Neolithic environment.

Acknowledgements The MSA modelling software was developed by Richard Middleton; for access to this please contact Jane Bunting (dr.mairi.jane.bunting@gmail.com). We thank Kirsty Harding for help with the figures. We are grateful to Ralph Fyfe for supplying the raw data for Figure 11, and thank him and four anonymous reviewers for helpful and constructive comments on an earlier version of this manuscript.

Funding Information Modelling has been supported by a European Research Council Advanced Investigator Grant (295412; 2012-2017), The Times of Their Lives (www.totl.eu), led by Alasdair Whittle and Alex Bayliss.

Open Access This article is distributed under the terms of the Creative Commons Attribution 4.0 International License (http://creativecommons.org/licenses/by/4.0/), which permits unrestricted use, distribution, and reproduction in any medium, provided you give appropriate credit to the original author(s) and the source, provide a link to the Creative Commons license, and indicate if changes were made.

\section{References}

Aalbersberg, G. (2000). The alluvial fringes of the Somerset Levels. Unpublished PhD thesis, University of Exeter.

Aalbersberg, G., \& Brown, T. (2011). The environment and context of the Glastonbury lake village: a reassessment. Journal of Wetland Archaeology, 10, 136-151.

Allen, M. J. (2017). The southern English chalklands: molluscan evidence for the nature of post-glacial woodland cover. In M. J. Allen (Ed.), Molluscs in archaeology; methods, approaches and applications (pp. 144-164). Oxford: Oxbow Books.

Beckett, S. C., \& Hibbert, F. A. (1978). The influence of man on the vegetation of the Somerset Levels - a summary. Somerset Levels Papers, 4, 86-89.

Behre, K. E. (1981). The interpretation of anthropogenic indicators in pollen diagrams. Pollen et Spores, 23, $225-245$.

Bell, M. (2015). Chapter 6: Shapwick Burtle Mesolithic site and the Sweet Track. In M. Bell, R. Brunning, R. Batchelor, T. Hill, \& K. Wilkinson (Eds.), The Mesolithic of the wetland/dryland edge in the Somerset Levels: revised report November 2015 (Historic England Reference 6624) (pp. 111-178). Swindon: Historic England.

Bell, M., Allen, M. J., Smith, R. W., \& Johnson, S. (2008). Molluscan and sedimentary evidence for the palaeoenvironmental history of Hambledon Hill and its surroundings. In R. Mercer, F. Healy, H. Hill, \& E. Dorset (Eds.), Excavation and survey of a Neolithic monument complex and its surrounding landscape (pp. 412-453). Swindon: English Heritage.

Berglund, B. E., Larsson, L., Lewan, N., Skansjö, S., \& Riddersporre, M. (1991). The cultural landscape during 6000 years in southern Sweden - the Ystad Project. In Ecological Bulletins 41. Copenhagen: Mungsgaard.

Berglund, B.E., Birks, H.J.B, Ralska-Jasiewiczowa, M. \& Wright, H.E. (1996). Palaeoecological events during the last 15,000 years: regional synthesis of palaeoecological studies in lakes and mires in Europe. Chichester: John Wiley.

Binney, H. A., Waller, M. P., Bunting, M. J., \& Armitage, R. A. (2005). The interpretation of fen carr pollen diagrams: the representation of the dry land vegetation. Review of Palaeobotany and Palynology, 134, 197-218.

Birks, H. H., \& Birks, H. J. B. (2000). Future uses of pollen analysis must include plant macrofossils. Journal of Biogeography, 27, 31-35. 
Blaauw, M., \& Christen, J. A. (2011). Flexible paleoclimate age-depth models using autoregressive gamma process. Bayesian Analysis, 6, 457-474.

Bradley, R. (2007). The prehistory of Britain and Ireland. Cambridge: Cambridge University Press.

Bronk Ramsey, C. (2009). Bayesian analysis of radiocarbon dates. Radiocarbon, 51, 337-360.

Brown, T. (1997). Clearances and clearings: deforestation in Mesolithic/Neolithic Britain. Oxford Journal of Archaeology, 162, 133-146.

Brunning, R. (2013). Somerset's peatland archaeology. Managing and investigating a fragile resource. Oxford: Oxbow Books.

Bunting, M. J. (2008). Pollen in wetlands: using simulations of pollen dispersal and deposition to better interpret the pollen signal. Biodiversity and Conservation, 17, 2079-2096.

Bunting, M. J., \& Farrell, M. (2018). Seeing the wood for the trees: recent advances in the reconstruction of woodland in archaeological landscapes using pollen data. Environmental Archaeology, 23, 228-239.

Bunting, M. J., \& Middleton, R. (2009). Equifinality and uncertainty in the interpretation of pollen data: the Multiple Scenario Approach to reconstruction of past vegetation mosaics. The Holocene, 19, 799-803.

Bunting, M. J., Gaillard, M.-J., Sugita, S., Middleton, R., \& Broström, A. (2004). Vegetation structure and pollen source area. The Holocene, 14, 651-660.

Bunting, M. J., Farrell, M., Bayliss, A., Marshall, P., \& Whittle, A. (2018). Maps from mud - using the Multiple Scenario Approach to reconstruct land cover dynamics from pollen records: a case study of two Neolithic landscapes. Frontiers in Ecology and Evolution, 6, 36. https://doi.org/10.3389/fevo.2018.00036.

Caseldine, C., \& Fyfe, R. (2006). A modelling approach to locating and characterizing elm decline/landnam landscapes. Quaternary Science Reviews, 25, 632-644.

Caseldine, C., Fyfe, R., Langdon, C., \& Thompson, G. (2007). Simulating the nature of vegetation communities at the opening of the Neolithic on Achill Island, Co. Mayo, Ireland - the potential role of models of pollen dispersal and deposition. Review of Palaeobotany and Palynology, 144, 135-144.

Caseldine, C., Fyfe, R., \& Hjelle, K. (2008). Pollen modelling, palaeoecology and archaeology: virtualisation and/or visualisation of the past? Vegetation History and Archaeobotany, 17, 543-549.

Chapman, H. P., \& Gearey, B. R. (2000). Palaeoecology and the perception of prehistoric landscapes: some comments on visual approaches to phenomenology. Antiquity, 74, 316-319.

Clark, J. G. D., \& Godwin, H. (1962). The Neolithic in the Cambridgeshire fens. Antiquity, 36, 10-23.

Coles, J. M. (1989). The Somerset Levels Project 1973-1989. Somerset Levels Papers, 15, 5-33.

Coles, B., \& Brunning, R. (2009). Following the Sweet Track. In G. Cooney, K. Becker, J. Coles, M. Ryan, \& S. Sievers (Eds.), Relics of old decency: archaeological studies in later prehistory (pp. 25-37). Dublin: Wordwell.

Coles, B., \& Coles, J. M. (1986). Sweet Track to Glastonbury: the Somerset Levels in prehistory. London: Thames and Hudson.

Coles, B., \& Coles, J. (1992). Passages of time. Archäologische Mitteilungen aus Nordwestdeutschland, 15, 29-44.

Coles, J. M., Hibbert, F. A., Orme, B. J., Pettit, M., Rushton, D., \& Switsur, V. R. (1973). Prehistoric roads and tracks in Somerset, England: 3. The Sweet Track. Proceedings of the Prehistoric Society, 39, 256-293.

Cummings, V. (2017). The Neolithic of Britain and Ireland. Abingdon: Routledge.

Diers, S. (2018). Mensch-Umweltbeziehungen zwischen 4000 und 2200 cal BC: Vegetationsgeschichtlichen Untersuchungen an Mooren und trichterbecherzeitlichen Fundplätzen der Altmark. Bonn: Habelt.

Druce, D. (2000). Mesolithic to Romano-British archaeology and environmental change of the Severn Estuary, England. Unpublished PhD thesis, University of Bristol.

Edmonds, M. (1999). Ancestral geographies of the Neolithic: landscapes, monuments and memory. London: Routledge.

Erdtman, G. (1928). Studies in the postarctic history of the forests of Northwestern Europe. Investigations in the British Isles. Geologiska Föreningen i Stockholm Förhandlingar, 50, 123-192.

Evans, C., \& Hodder, I. (2006). A woodland archeology: Neolithic sites at Haddenham. Cambridge: McDonald Institute for Archaeological Research.

French, C., Lewis, H., Allen, M. J., Green, M., Scaife, R., \& Gardiner, J. (2007). Prehistoric landscape development and human impact in the upper Allen valley, Cranborne Chase, Dorset. Cambridge: McDonald Institute Monographs.

Fyfe, R. (2006). GIS and the application of a model of pollen deposition and dispersal: a new approach to testing landscape hypotheses using the POLLANDCAL models. Journal of Archaeological Science, 33, 483-493.

Fyfe, R., Caseldine, C., \& Gillings, M. (2010). Pushing the boundaries of data? Issues in the construction of rich visual past landscapes. Quaternary International, 220, 153-159.

Fyfe, R. M., Twiddle, C., Sugita, S., Gaillard, M. J., Barratt, P., Caseldine, C. K., Dodson, J., Edwards, K. J., Farrell, M., Froyd, C., Grant, M. J., Huckerby, E., Innes, J., Shaw, H., \& Waller, M. (2013). The Holocene 
vegetation cover of Britain and Ireland: overcoming problems of scale and discerning patterns of openness. Quaternary Science Reviews, 73, 132-148.

Gillings, M., Pollard, J., Wheatley, D., \& Peterson, R. (2008). Landscape of the megaliths: excavation and fieldwork on the Avebury monuments, 1997-2003. Oxford: Oxbow Books.

Godwin, H. (1941). Pollen-analysis and Quaternary geology. Proceedings of the Geologists' Association, 52, 328-361.

Godwin, H. (1960). Prehistoric wooden trackways of the Somerset Levels: their construction, age and relation to climate change. Proceedings of the Prehistoric Society, 26, 1-36.

Grant, M. J., \& Waller, M. P. (2017). Resolving complexities of pollen data to improve interpretation of past human activity and natural processes. In M. Williams, T. Hill, I. Boomer, \& I. P. Wilkinson (Eds.), The archaeological and forensic applications of microfossils: a deeper understanding of human history (pp. 103-119). Bath: Special Publication of the Micropalaeontological Society, Geological Society Publishing House.

Grant, M. J., Waller, M. P., \& Groves, J. A. (2011). The Tilia decline: vegetation change in lowland Britain during the mid and late Holocene. Quaternary Science Reviews, 30, 394-408.

Green, G. W. (1992). British regional geology: Bristol and Gloucester region. London: HMSO.

Harris, O. J. T., \& Cipolla, C. N. (2017). Archaeological theory in the new millennium: introducing current perspectives. Abingdon: Routledge.

Haslett, S. K., Howard, K. L., Margetts, A. J., \& Davies, P. (2001). Holocene stratigraphy and evolution of the northern coastal plain of the Somerset Levels. Proceedings of the Cotteswold Naturalist Field Club, 42, 78-88.

Hellman, S., Gaillard, M.-J., Bunting, M. J., \& Mazier, F. (2009). Estimating the relevant source area of pollen in the past cultural landscapes of southern Sweden - a forward modelling approach. Review of Palaeobotany and Palynology, 153, 259-271.

Hey, G., \& Robinson, M. (2016). Settlement and landscape. In G. Hey, C. Bell, C. Dennis, \& M. Robinson (Eds.), Yarnton: Neolithic and Bronze Age settlement and landscape (pp. 21-50). Oxford: Oxford Archaeology.

Hill, T. C. B., Hill, G. E., Brunning, R., Banerjea, R. Y., Fyfe, R. M., Hogg, A. G., Jones, J., Perez, M., \& Smith, D. (2019). Glastonbury lake village revisited: a multi-proxy palaeoenvironmental investigation of an Iron Age wetland settlement. Journal of Wetland Archaeology. https://doi.org/10.1080/14732971.2018.1560064.

Hillam, J., Groves, C., Brown, D. M., Baillie, M. G. L., Coles, J. M., \& Coles, B. J. (1990). Dendrochronology of the English Neolithic. Antiquity, 64, 211-220.

Hinz, M., Fesser, I., \& Sjögren, K.-G. (2012). Demography and the intensity of cultural activities: an evaluation of Funnel Beaker societies (4200-2800 cal BC). Journal of Archaeological Science, 39, 3331-3340.

Hjelle, K. L., \& Lødøen, T. G. (2017). Dating of rock art and the effect of human activity on vegetation: the complementary use of archaeological and scientific methods. Quaternary Science Reviews, 168, 194-207.

Housley, R. A. (1988). The environmental context of the Glastonbury lake village. Somerset Levels Papers, 14, 63-82.

Hultberg, T., Gaillard, M.-J., Grundmann, B., \& Lindbladh, M. (2015). Reconstruction of past landscape openness using the Landscape Reconstruction Algorithm (LRA) applied on three local pollen sites in a southern Swedish biodiversity hotspot. Vegetation History and Archaeobotany, 24, 253-266.

Ingold, T. (1993). The temporality of the landscape. World Archaeology, 25, 152-174.

Iversen, J. (1941). Landnam i Denmarks Stenalder. Danmarks Geologiske Undersøgelse II, 66, 1-67.

Iversen, J. (1949). The influence of prehistoric man on vegetation. Danmarks Geologiske Undersøgelse IV, 6, 1-25.

Jacomet, S., Ebersbach, R., Akeret, Ö., Antolí, F., Baum, T., Bogaard, A., Brombacher, C., Bleicher, N. K., HeitzWeniger, A., Hüster-Plogmann, H., Gross, E., Kühn, M., Rentzel, P., Steiner, B. L., Wick, L., \& Schibler, M. (2016). On-site data casts doubt on the hypothesis of shifting cultivation in the late Neolithic (c. 4300-2400 cal. BC): landscape management as an alternative paradigm. The Holocene, 26, 1858-1874.

Knitter, D., Brozio, J. P., Dörfler, W., Duttmann, R., Feeser, I., Hamer, W., Kirleis, W., Müller, J., \& Nakoinz, O. (2019). Transforming landscapes: modeling land-use patterns of environmental borderlands. The Holocene. https://doi.org/10.1177/0959683619857233.

McLaughlin, T. R., Whitehouse, N. J., Schulting, R. J., McClatchie, M., Barratt, P., \& Bogaard, A. (2016). The changing face of Neolithic and Bronze Age Ireland: a big data approach to the settlement and burial records. Journal of World Prehistory, 29, 17-153.

Mitchell, F. J. G. (2005). How open were European primeval forests? Hypothesis testing using palaeoecological data. Journal of Ecology, 93, 168-177.

Molloy, K., \& O’Connell, M. (1995). Palaeoecological investigations towards the reconstruction of environment and land-use changes during prehistory at Ceide Fields, western Ireland. Probleme der Küstenforschung im südlichen Nordseegebiet, 23, 187-225.

Noble, G. (2017). Woodland in the Neolithic of Northern Europe: the forest as ancestor. Cambridge: Cambridge University Press. 
Peglar, S. (2006). The Ouse channel Flandrian sequence. In C. Evans \& I. Hodder (Eds.), A woodland archeology: Neolithic sites at Haddenham (pp. 26-29). Cambridge: McDonald Institute for Archaeological Research.

Perry, G. L. W., Wainwright, J., Etherington, T. R., \& Wilmshurst, J. M. (2016). Experimental simulation: using generative modeling and palaeoecological data to understand human-environment interactions. Frontiers in Ecology and Evolution, 4, 109. https://doi.org/10.3389/fevo.2016.00109.

Pollard, J. (1999). 'These places have their moments': thoughts on settlement practices in the British Neolithic. In J. Brück \& M. Goodman (Eds.), Making places in the prehistoric world: themes in settlement archaeology (pp. 76-93). London: UCL Press.

Pollard, J., Allen, M., Cleal, R., Snashall, N., Gunter, J., Roberts, V., \& Robinson, D. (2012). East of Avebury: tracing prehistoric activity and environmental change in the environs of Avebury henge (excavations at Rough Leaze 2007). Wiltshire Archaeological and Natural History Magazine, 105, 1-20.

Prentice, I. C. (1985). Pollen representation, source area and basin size: towards a unified theory of pollen analysis. Quaternary Research, 23, 76-86.

Prentice, I. C. (1988). Records of vegetation in time and space: the principles of pollen analysis. In B. Huntley \& T. Webb III (Eds.), Vegetation history (pp. 17-42). Dordrecht: Kluwer.

Ray, K., \& Thomas, J. (2018). Neolithic Britain: the transformation of social worlds. Oxford: Oxford University Press.

Reimer, P. J., Bard, E., Bayliss, A., Beck, J. W., Blackwell, P. G., Bronk Ramsey, C., Buck, C. E., Cheng, H., Edwards, R. L., Friedrich, M., Grootes, P. M., Guilderson, T. P., Haflidason, H., Hajdas, I., Hatté, C., Heaton, T. J., Hoffmann, D. L., Hogg, A. G., Hughen, K. A., Kaiser, K. F., Kromer, B., Manning, S. W., Niu, M., Reimer, R. W., Richards, D. A., Scott, E. M., Southon, J. R., Staff, R. A., Turney, C. S. M., \& van der Plicht, J. (2013). IntCal13 and Marine13 radiocarbon age calibration curves 0-50,000 years cal BP. Radiocarbon, 55, 1869-1887.

Runkle, J. R. (1982). Patterns of disturbance in some old-growth mesic forests of eastern North America. Ecology, 63, 1533-1546.

Shennan, I., \& Horton, B. (2002). Holocene land- and sea-level changes in Great Britain. Journal of Quaternary Science, 17, 511-526.

Smith, D., Whitehouse, N., Bunting, M. J., \& Chapman, H. (2010). Can we characterise 'openness' in the Holocene palaeoenvironmental record? Modern analogue studies of insect faunas and pollen spectra from Dunham Massey deer park and Epping Forest, England. The Holocene, 20, 215-229.

Stevens, C. J., \& Fuller, D. Q. (2012). The case for a Bronze Age agricultural revolution in the British Isles. Antiquity, 86, 707-722.

Sturt, F., Garrow, D., \& Bradley, S. (2013). New models of North West European Holocene palaeogeography and inundation. Journal of Archaeological Science, 40, 3963-3976.

Sturt, F., Standen, T., Grant, M. \& Dix, J. (2016). Determining potential: onshore/offshore prehistory. Unpublished report, University of Southampton.

Sugita, S. (1993). A model of pollen source area for an entire lake surface. Quaternary Research, 39, $239-244$.

Sugita, S. (1994). Pollen representation of vegetation in Quaternary sediments: theory and method in patchy vegetation. Journal of Ecology, 82, 881-897.

Sugita, S. (2007a). Theory of quantitative reconstruction of vegetation I: pollen from large sites REVEALS regional vegetation composition. Holocene, 17, 229-241.

Sugita, S. (2007b). Theory of quantitative reconstruction of vegetation II: all you need is LOVE. Holocene, 17, 243-257.

Sugita, S., Gaillard, M.-J., \& Broström, A. (1999). Landscape openness and pollen records: a simulation approach. The Holocene, 9, 409-421.

Svenning, J.-C. (2002). A review of natural vegetation openness in north-western Europe. Biological Conservation, 104, 133-148.

Thomas, J. (2013). The birth of Neolithic Britain. Oxford: Oxford University Press.

Tilley, C. (1994). A phenomenology of landscape: places, paths and monuments. Oxford: Berg.

Tinsley, H. M. (2000). Pollen analysis of sediment samples from Trenches L, A and H1, Walpole landfill site, Pawlett, Somerset. University of Bristol: Unpublished report.

Tinsley, H. M. (2007). Pollen analysis of peat samples from Borehole A Shapwick Heath. In C. Gerrard \& M. Aston (Eds.), The Shapwick Project, Somerset: a rural landscape explored (pp. 842-852). Leeds: Maney.

Tipping, R., Bunting, M. J., Davies, A. L., Murray, H., Fraser, S., \& McCulloch, R. (2009). Modelling land use around an early Neolithic timber 'hall' in north east Scotland from high spatial resolution pollen analyses. Journal of Archaeological Science, 36, 140-149.

Trondman, A. K., Gaillard, M.-J., Mazier, F., Sugita, S., Fyfe, R., Nielsen, A. B., Twiddle, C., Barratt, P., Birks, H. J., Bjune, A. E., Björkman, L., Broström, A., Caseldine, C., David, R., Dodson, J., Dörfler, W., Fischer, E., Geel, 
B., Giesecke, T., Hultberg, T., Kalnina, L., Kangur, M., Knaap, P., Koff, T., Kuneš, P., Lagerås, P., Latałowa, M., Lechterbeck, J., Leroyer, C., Leydet, M., Lindbladh, M., Marquer, L., Mitchell, F. J., Odgaard, B. V., Peglar, S. M., Persson, T., Poska, A., Rösch, M., Seppä, H., Veski, S., \& Wick, L. (2015). Pollen-based quantitative reconstructions of Holocene regional vegetation cover (plant-functional types and land-cover types) in Europe suitable for climate modelling. Global Change Biology, 21, 676-697.

Vera, F. W. M. (2000). Grazing ecology and forest history. Wallingford: CABI Publishing.

Wells, J., Weir, D. \& Brunning, R. (1999). Excavation of a possible terminal of the Sweet Track and pollen analysis of associated mid-Holocene peat. Unpublished report, Somerset County Council.

Whitehouse, N. J., \& Smith, D. (2010). How fragmented was the British Holocene wildwood? Perspectives on the "Vera" grazing debate from the fossil beetle record. Quaternary Science Reviews, 29, 539-553.

Whitehouse, N. J., Schulting, R. J., McClatchie, M., Barratt, P., McLaughlin, T. R., Bogaard, A., Colledge, S., Marchant, R., Gaffrey, J., \& Bunting, M. J. (2014). Neolithic agriculture on the European western frontier: the boom and bust of early farming in Ireland. Journal of Archaeological Science, 51, 181-205.

Whittle, A. (2018). The times of their lives: hunting history in the archaeology of Neolithic Europe. Oxford: Oxbow Books.

Whittle, A., Healy, F., \& Bayliss, A. (2011). Gathering time: dating the early Neolithic enclosures of southern Britain and Ireland. Oxford: Oxbow Books.

Woodbridge, J., Fyfe, R. M., Roberts, N., Downey, S., Edinborough, K., \& Shennan, S. (2014). The impact of the Neolithic agricultural transition in Britain: a comparison of pollen-based land-cover and archaeological ${ }^{14} \mathrm{C}$ date-inferred population change. Journal of Archaeological Science, 51, 216-224.

Publisher's Note Springer Nature remains neutral with regard to jurisdictional claims in published maps and institutional affiliations.

\title{
Affiliations
}

Michelle Farrell ${ }^{1,2,3} \cdot$ M. Jane Bunting ${ }^{3}$. Fraser Sturt ${ }^{4}$ - Michael Grant ${ }^{5} \cdot$ Gerard Aalbersberg $^{6} \cdot$ Rob Batchelor $^{7}$ - Alex Brown ${ }^{8,9} \cdot$ Denise Druce $^{10} \cdot$ Tom Hill $^{11}$. Arthur Hollinrake $^{12}$. Julie Jones ${ }^{13} \cdot$ Heather Tinsley ${ }^{13}$ - Alex Bayliss ${ }^{14,15}$ - Peter Marshall $^{14}$. Suzi Richer ${ }^{16,17}$. Alasdair Whittle ${ }^{18}$

\author{
Michelle Farrell \\ ac5086@ coventry.ac.uk \\ M. Jane Bunting \\ m.j.bunting@hull.ac.uk \\ Fraser Sturt \\ F.Sturt@soton.ac.uk \\ Michael Grant \\ M.J.Grant@soton.ac.uk \\ Gerard Aalbersberg \\ g.aalbersberg@agea-advies.nl \\ Rob Batchelor \\ c.r.batchelor@reading.ac.uk \\ Alex Brown
a.brown@wessexarch.co.uk \\ Denise Druce \\ denise.druce@oxfordarch.co.uk \\ Tom Hill \\ thomas.hill@nhm.ac.uk
}


Arthur Hollinrake

arthurhollinrake@yahoo.co.uk

Julie Jones

juliedjones@blueyonder.co.uk

Heather Tinsley

tinsleyheather@btinternet.com

Alex Bayliss

alex.bayliss@historicengland.org.uk

Peter Marshall

peter.marshall@historicengland.org.uk

Suzi Richer

suzi.richer@york.ac.uk

1 School of Energy, Construction and Environment, Sir John Laing Building, Coventry University, Much Park Street, Coventry CV1 2LT, UK

2 Centre for Agroecology, Water and Resilience, Coventry University, Wolston Lane, Ryton-on-Dunsmore, Coventry CV8 3LJ, UK

3 School of Environmental Sciences, University of Hull, Cohen Building, Cottingham Road, Hull HU6 7RX, UK

4 Archaeology, University of Southampton, Avenue Campus, Highfield, Southampton SO17 1BF, UK

5 Coastal and Offshore Archaeological Research Services, Ocean and Earth Science, National Oceanography Centre Southampton, University of Southampton, European Way, Southampton SO14 $3 \mathrm{ZH}, \mathrm{UK}$

6 AGEA Advies, Pieterburen, The Netherlands and Groningen Institute of Archaeology, 9712 ER Groningen, The Netherlands

7 Quaternary Scientific, School of Archaeology, Geography and Environmental Science, The University of Reading, Whiteknights, PO Box 227, Reading RG6 6AB, UK

8 Wessex Archaeology, Portway House, Old Sarum Park, Salisbury SP4 4ED, UK

9 Department of Archaeology, University of Reading, Whiteknights, Reading RG6 6AB, UK

10 Oxford Archaeology North, Mill 3, Moor Lane Mills, Moor Lane, Lancaster LA1 1QD, UK

11 Natural History Museum, Cromwell Road, London SW7 5BD, UK

12 Hollinrake Archaeology, 12 Bove Town, Glastonbury BA6 8JE, UK

13 formerly Environmental Archaeology Laboratory, School of Geographical Sciences, University of Bristol, University Road, Bristol BS8 1SS, UK

14 Historic England, Cannon Bridge House, London EC4R 2YA, UK

15 Biological and Environmental Sciences, University of Stirling, Stirling FK9 4LA, UK

16 Department of Archaeology, University of York, King's Manor, York YO1 7EP, UK

17 Environment Department, Wentworth Way, University of York, York YO10 5NG, UK

18 Department of Archaeology and Conservation, John Percival Building, Cardiff University, Colum Drive, Cardiff CF10 3EU, UK 